\title{
The Reflection on the Magnitude and Disasters of BEPS Schemes
}

\author{
Haiyan Xu \\ The Law School, University of International Business \& Economics, Beijing, China \\ Email: uibexhy@sina.com
}

How to cite this paper: $\mathrm{Xu}, \mathrm{H}$. Y. (2019). The Reflection on the Magnitude and Disasters of BEPS Schemes. Beijing Law Review, 10, 730-768.

https://doi.org/10.4236/blr.2019.104041

Received: May 9, 2019

Accepted: August 12, 2019

Published: August 15, 2019

Copyright (c) 2019 by author(s) and Scientific Research Publishing Inc. This work is licensed under the Creative Commons Attribution International License (CC BY 4.0).

http://creativecommons.org/licenses/by/4.0/

\begin{abstract}
To promote the maximum consensus of the global community on the implementation of the OECD/G20 Final BEPS Package, this paper investigated the magnitude and disasters of BEPS schemes by comparative research and empirical data. This paper analyzed the relevance of ETRs to the magnitude of BEPS, the ratio of corporate tax revenue in GDP in the process of globalization, the relevance of the FDI flows to BEPS, the relevance of the widespread conduit or SPE structures to BEPS schemes and the magnitude of BEPS schemes of U.S.-based MNEs. As the research findings, this paper highlighted the complicated disasters of over speculative BEPS schemes. The BEPS schemes have eroded the integrity of tax bases in both source and residence jurisdictions, deteriorated the quality of the public goods in all relevant jurisdictions, fundamentally undermined the tax justice, imposed unfair burden on domestic taxpayers especially the individuals and small businesses, distorted the free and fair mechanism of market competition, undermined the efficiency of rational market in optimal allocation of the resources and created a booming intermediary industry assisting BEPS, undermined the reasonable trust of global taxpayers in the fairness and integrity of the tax law, hindered the voluntary compliance by the public taxpayers, and injured the reputation of the community of MNEs and worsened off the global business ecology.
\end{abstract}

\section{Keywords}

BEPS Schemes, MNEs, International Tax Regulation, Global Market Economy

\section{Introduction}

BEPS is not only a headline news covered by global mainstream media, but also a top priority on the agenda of international organizations. In Saint Petersburg 
in September 2013, the G20 Leaders endorsed an Action Plan to address base erosion and profit shifting (BEPS). On October 5, 2015, the OECD and G20 released the final BEPS package of 13 reports together with the 2015 Final Report of Explanatory Statement (Avi-Yonah \& Xu, 2016). The BEPS package represents the first substantial and overdue renovation of the international tax standards in almost a century, and also an unprecedented turning point in the history of international tax law. ${ }^{1}$ Although the real effect of the BEPS project remains to be evaluated, there is no doubt that the BEPS project will help to tackle the BEPS issues, to empower the governments in collection of tax from the MNEs in a coordinate manner, to level the playing filed for the business community and for the governments, and to restore the public confidence on tax law.

\section{The Definition of BEPS}

BEPS is the abbreviation of "Base Erosion and Profit Shifting", which refers to the complicated set of aggressive tax planning schemes committed by the multinational enterprises (MNEs), aiming at shifting the taxable profits from the jurisdiction where income producing activities are conducted or value is created, into a third jurisdiction of more favorable tax treatment in the form of no or low tax. In other words, BEPS refers to tax planning that makes use of gaps in the interaction of different tax systems to artificially reduce taxable income or shift profits to low-tax jurisdictions in which little or no economic activity is performed, resulting in little or no overall corporate tax being paid.

The key feature of BEPS scheme is that there is substantial segregation between the location where MNEs' actual business activities and investment take place and the location where MNEs' profits are reported for tax purposes.

There are many different, sophisticated schemes, regardless of legitimacy or legality, to erode the tax base. By far, the tax scholars and experts have identified three major behaviors resulting in the loss or reduction of the tax revenue receipts: tax evasion, tax avoidance, and licit tax savings.

Although there are different and even conflicting interpretations of the exact definition, key feature and core schemes of the three behaviors, there are some preliminary consensus among the mainstream authorities. Tax evasion can be synthetically defined as intentional illegal behaviors, i.e., behaviors involving a direct violation of tax law, in order to escape payment of taxes. Tax avoidance can be defined as all illegitimate (but not necessarily illegal) behaviors aimed at reducing tax liability. These behaviors do not violate the articles of the law but clearly violate its spirit. Licit tax savings can be defined as commonly accepted forms of tax behaviors that contradict neither the law nor its spirit and are intended to reduce the tax burden. This category can also be referred to as "legitimate tax planning"2 (Avi-yonah et al., 2011).

${ }^{1}$ Reuven S. Avi-Yonah, Haiyan Xu: "Evaluating BEPS: A Reconsideration of the Benefits Principle and Proposal for UN Oversight, Harvard Business Law Review, Vol 6, No.2, Summer 2016.

${ }^{2}$ Reuven S. Avi-yonah, Nicola Sartori, and Omri Marian: Global Perspectives on income taxation law, Oxford University Press (2011) p. 101, 102. 
Tested by the standards of legitimacy and legality, there are four similar but different sets of strategies for the MNEs to escape or reduce the tax obligation and erode the tax base. The first category of strategy is both legitimate and legal, represented by licit tax savings. The second category of strategy is illegitimate but legal, represented by tax avoidance. The third category of strategy is both illegitimate and illegal, represented by tax evasion. The fourth category of strategy is legitimate, but illegal. As the first three categories based on the assumption that the tax law is legitimate fair and justified, the fourth category should be ignored in the case of illegitimacy, unfairness and unjustness of tax law. Of course, the last category is relevant to the reorientation of tax law philosophy, optimization of tax law policy, examination of the global competition of tax jurisdictions, or even the application of constitutionalism in domestic jurisdiction.

Although profit shifting is not the only and single way to erode the tax base, profit shifting is the most frequently used strategy. That is why the two phrases "Base Erosion" and "Profit Shifting" are put together in forming a new phrase "BEPS". "Base Erosion" refers to the purpose of BEPS schemes, "Profit Shifting" refers to the actions to erode the tax base. From the narrow perspective, BEPS strategy could be defined as tax avoidance. But from the broad perspective, BEPS strategy could be defined as all the four above-mentioned behaviors, including but not confined to tax evasion, tax avoidance, and licit tax savings. Considering the fact that MNEs usually take highly sophisticated and comprehensive strategies to escape or reduce their tax obligation, this dissertation takes broad approach to the concept of BEPS, for the purpose of comprehensive research on the BEPS challenges.

Logically speaking, "Base Erosion" describes the consequence, but not the purpose, of BEPS schemes. Because, the primary and proximate purpose is to avoid the obligation or duty to pay appropriate corporate income tax they are supposed to pay under normal tax law regime. Therefore, the purpose of BEPS schemes is to avoid the tax, the consequence of BEPS schemes is base erosion. It should be more accurate to change the name of "BEPS" to "TAPS" (Tax Avoidance and Profit Shifting). Anyway, given the fact that "BEPS" already has been widely used, considering that tax base erosion and tax duty avoidance are the two sides of the same coin, I continue to use "BEPS" in this dissertation, for the purpose of convenience in discussion,

The phenomenon of BEPS is also called the problem of "Homeless Income (HI)", because the corporate income is not competitively taxed in the source country, and the country of residence provides a concessionary or no tax rate for it. (Wells \& Lowell, 2014) In short, the corporate income is "homeless" because it is not subject to competitive tax in any jurisdiction. ${ }^{3}$ The term "Double Non-Taxation" (DNT) is also the similar term to describe the problem of BEPS. For the purpose of brevity in this dissertation, I will use the most commonly ${ }^{3}$ According to Bret Wells and Cym Lowell, "competitive" tax refers to prevailing levels of corporate taxation in developed countries. See, Bret Wells and Cym Lowell, "Tax Base Erosion: Reformation of Section 482's Arm's Length Standard”, 15 Fla. Tax Rev, 737, 2014. 
used term, "BEPS".

BEPS is made possible not only by the MNEs' intentional tax planning schemes, but also by the incoherence of international tax law between and among the jurisdictions.

BEPS is not only a headline news covered by global mainstream media, but also a target vocally criticized by the civil society including the NGOs and NPOs, and strongly condemned by the global community. Many jurisdictions and international organizations have expressed their deep concern about the BEPS problem.

The BEPS problem has also become a top priority on the agenda of international organizations. The G20 leaders meeting in Mexico on 18-19 of June 2012 explicitly identified "the need to prevent base erosion and profit shifting" in their final Declaration. The final communiqué of the G20 finance ministers meeting of 5-6 of November 2012 stated, "We also welcome the work that the OECD is undertaking into the problem of base erosion and profit shifting and look forward to a report about progress of the work at our next meeting". The UK's Chancellor of the Exchequer and Germany's Minister of Finance, issued a joint statement, later joined by France's Economy and Finance Minister, calling for co-ordinated action to strengthen international tax standards and urging their counterparts to back efforts by the OECD to identify possible gaps in tax laws. ${ }^{4}$

In Saint Petersburg in September 2013, the G20 Leaders endorsed an Action Plan to address base erosion and profit shifting (BEPS). G20 Leaders' Declaration of September, 2013 made it clear that, "Cross-border tax evasion and avoidance undermine our public finances and our people's trust in the fairness of the tax system. Today, we endorsed plans to address these problems and committed to take steps to change our rules to tackle tax avoidance, harmful practices, and aggressive tax planning". This Declaration devoted three paragraph to address BEPS, tackle tax avoidance, and promote tax transparency and automatic exchange of information. ${ }^{5}$

In response to this call, the OECD/G20 BEPS Project was launched to develop the measures envisaged in the 15-point Action Plan, bringing together all OECD and G20 members working on an equal footing and with an intensive and regular consultation with an additional more than 80 countries.

On October 5, 2015, the OECD and G20 released the final BEPS package of 13 reports together with the 2015 Final Report of Explanatory Statement. It was only two years since the G20 leaders endorsed the ambitious and comprehensive 15-point Action Plan to address BEPS at their meeting in St. Petersburg on 5-6 September 2013.

The BEPS package represents the first substantial and overdue renovation of the international tax standards in almost a century. ${ }^{6}$ The BEPS package is an un-

${ }^{4}$ Addressing Base Erosion and Profit Shifting@ OECD 2013, P.21

${ }^{5}$ https://g20.org/wp-content/uploads/2014/12/SaintPetersburgDeclarationENG0.pdf

${ }^{6}$ OECD (2015), Explanatory Statement, OECD/G20 Base Erosion and Profit Shifting Project, OECD, p. 5. 
precedented turning point in the history of international tax law. The mission of BEPS package is to align the location of taxable profits with the location of economic activities and value creation. Some generally accepted principles of international tax law, including the single tax principle, the benefit principle, the anti-discrimination principle and the transparency principle have been reflected in many respects.

The BEPS project sent a clear message to the MNEs that BEPS will not be tolerated in the future. While acknowledging the complexity of BEPS as well as methodological and data limitations, the scale of global corporate income tax revenue losses could be between USD 100 to 240 billion annually. ${ }^{7}$ Remarkably, with recent announcements indicating important changes to tax structuring by some large MNEs, the impact on taxpayer behavior can already be seen before implementation is even fully underway. ${ }^{8}$

Although the real effect of the BEPS project remains to be evaluated, there is no doubt that the BEPS project will help to tackle the BEPS issues, to empower the governments in collection of tax from the MNEs in a coordinate manner, to level the playing filed for the business community and for the governments, and to restore the public confidence on tax law.

\section{Seriousness of the Existence and Magnitude of Global BEPS Schemes}

\subsection{The Brief Review of Current Research on the Magnitude of BEPS Schemes}

Critiques and policy solutions to the BEPS problem should be neither simply based on the public perceptions nor on the common sense knowledge. Rationale and solid research findings on the existence and magnitude of BEPS are both necessary and challenging. In fact, a great number of serious research reports on the magnitude of BEPS have been published or released.

One of the key missions of the research projects is to choose some valid indicators capable of testing the seriousness of BEPS problem. In fact, various indicators have been used by the research projects. Some studies use the data on the ratio of the corporate income tax revenue to GDP or total tax revenues in major jurisdictions. Some studies use the data on foreign direct investment and the use of conduit structure of low or no tax special purpose entities (SPE). Some studies try to investigate the difference between the statutory tax rate and the effective tax rates (ETR) through either backward-looking or forward-looking approach, to prove the existence or absence of BEPS behavior. Although none of the indicators could be singled out as the unique panacea to test the existence and magnitude of the BEPS, it is the most feasible, even not most ideal way to encourage the research and development a range of indicators of BEPS problem.

Data is always a tricky issue. It is relatively easy to investigate the exact mag${ }^{7}$ OECD (2015), Explanatory Statement, OECD/G20 Base Erosion and Profit Shifting Project, OECD, p. 4

${ }^{8}$ Supra note, P. 9. 
nitude of BEPS schemes committed by high profile MNEs, especially listed corporations subject to very harsh disclosure requirements imposed by the securities law. There are usually more than one listed corporations in the multinational groups. But it is difficult to gather sufficient data from the less transparent, unlisted MNEs. Even the information disclosed by the listed corporations is not always reliable. One of the major reasons is that the listed corporation might only represent a very limited part of the huge and complicated empire of transnational corporate groups. In short, the conventional disclosure regimes of securities law is unable to capture all the information of ownership structures and business transactions of every branch or subsidiary within the cross boarder empire. That is why overwhelming interesting findings focus on the individual cases from the macro perspective, and it is more difficult and controversial when the academics turn to the whole picture of the magnitude of global BEPS problem.

The same data, processed by different methodologies, may lead to different or even opposite conclusions. The methodology does make difference. It is indicated that in some instances, the methodology was chosen and the data used seem to be driven more by the intention to support a given conclusion than to achieve a conclusion on the basis of the analysis. ${ }^{9}$

In my opinion, the strength of the credible research findings heavily depends on scientific and logical methodology. The mission of the research is to collect all relevant data and information on an objective basis, and to employ the appropriate methodology to process and analyze the data on a fair, objective and honest basis, and finally to draw conclusions. Certain interest groups and their advocates tend to keep an existing conclusion in mind before doing research. However, such methodology is negative and harmful in terms of selective data, biased methodology, flawed reasoning and invalid findings. Although OECD BEPS Report is reluctant to disclose the full details about such sort of research findings, it is necessary for the BEPS researchers to disclose their conflicts of interest or prejudice in their research reports.

Although none of the current research findings is the only conclusive, and legally binding evidence of the exact magnitude of BEPS schemes, the majority of research findings support the allegations of the existence of BEPS problem. Despite the difficulty in reaching solid conclusions about how much BEPS actually occurs, it is a common sense perception that BEPS has been increasingly adopted by MNEs to escape or lower their tax burden, with the assistance from professional expertise in most circumstances.

For instance, a number of scientific studies and data indicate that there is increased segregation between the location where actual business activities and investment take place and the location where profits are reported for tax purpose. ${ }^{10}$ Such segregation is the most fundamental feature of BEPS.

${ }^{9}$ Addressing Base Erosion and Profit Shifting (C) OECD 2013, P. 21.

${ }^{10}$ Ibid, P. 20. 


\subsection{The Relevance of ETRs to the Magnitude of BEPS}

There are always the difference between the statutory corporate income tax rate (headline rate) and the effective tax rates (ETRs), because of the indispensable costs arising from the translation of the tax law rules into the practice. Despite the complicated contributing factors to explain the difference between statutory corporate income tax rates and MNEs' effective tax rates (ETRs) applicable to the MNEs, ETR is one of significant indicators of the existence or the absence of BEPS behaviors.

The statutory corporate income tax rate in specific jurisdiction is the rate specified in the domestic tax law that governs corporate taxable income for the purpose of determining the amount of the taxpayer's tax liability. It cannot be taken alone as a reliable indicator of the effective tax burden on income generated at the corporate level. Therefore, it is more valuable for both MNEs and academics to pay more attention to the ETR.

Since the Tax Reform Act of 1986, new corporate tax preferences have widened the gap between gross income and taxable income. In 1987, gross corporate profits reported on tax returns were $\$ 328$ billion and taxable income was $\$ 312$ billion. Thus since 1987, taxable income has fallen to $68 \%$ from $95 \%$ of gross income. According to IRS, corporations had gross profits of $\$ 1.8$ trillion in 2007 and taxable income of $\$ 1.2$ trillion. Many corporations are so adept at manipulating the tax code that they pay no federal taxes at all. According to CTJ, 78 companies paid no federal income taxes at least one year between 2008 and 2010 (Bartlett, 2013). The data come from annual company reports and may not necessarily reflect actual tax payments on tax returns because of different accounting concepts. ${ }^{11}$

The corporate ETR is generally understood as the ratio of corporate income tax to a pre-tax measure of corporate profit over a given period of time. There are two approached to analyze the ETRs: backward-looking ETRs and forward-looking ETRs. Backward-looking ETRs, based on measures of actual taxes paid in dollar amount, could fairly reflect the actual tax burden of the MNEs in certain jurisdictions. While forward-looking effective corporate tax rates are derived from modeling a hypothetical investment project on a discounted cash flow basis and taking account of all the relevant tax provisions. Recent OECD work has developed approaches to factor in effects of cross-border tax planning ${ }^{12}$

Marginal effective corporate tax rates and average effective corporate tax rates are two important but different indicators in the category of the forward-looking effective corporate tax rates. Marginal effective corporate tax rates examine the tax treatment of pre-tax returns on the last unit of capital invested and in effect estimate how tax affects a firm's cost of capital. Average effective corporate tax rates are most helpful where MNEs have a choice about the country in which they could locate discrete, infra-marginal projects that yield more than the cost of capital.

\footnotetext{
${ }^{11}$ Bruce Bartlett (2013), "Effective Corporate Tax Rates”, New York Times, November 26, 2013. http://economix.blogs.nytimes.com/2013/11/26/effective-corporate-tax-rates/?r=0

${ }^{12}$ For the data, see, Addressing Base Erosion and Profit Shifting® OECD 2013, P. 19-p. 20.
} 
There are many ground breaking research projects on the ETR of MNEs. For instance, (Avi-Yonah \& Lahav, 2011) Prof. Avi-Yonah and Lahav pointed out that, despite the US statutory corporate tax rate being $10 \%$ higher than the average statutory corporate tax rate in the EU, the effective tax rates are comparable and that EU MNEs tend to have a higher ETR (on average approximately 34\%) than U.S.MNEs (on average approximately $30 \%) .{ }^{13}$

A study by the United States Bureau of Economic Analysis (BEA) (Yorgason, 2009) reports that effective average income tax rates borne in the period 2004-07 by United States parent companies $(22.8 \%$ in 2006) and U.S. affiliates of non-U.S. enterprises (28.8\% in 2006) are much higher than the average for foreign affiliates (14.6\% in 2006). ${ }^{14}$

National Bureau of Economic Research working paper found slightly different ETR results. The median ETRs for MNEs with headquarters in high-tax countries roughly double those in low-tax countries: MNEs domiciled in Japan face the highest ETRs (median ETRs of 37\%), followed by those domiciled in the U.S. (30\%), Australia (26\%), France and Germany (25\%), while MNEs domiciled in low-tax jurisdictions usually enjoy the lowest ETRs (14\%) ${ }^{15}$ (Markle \& Hackelford, 2011).

A study of the Greenlining Institute on the 30 top tech companies in the U.S. also supports the lower ETR level in the U.S. This study concludes that the ETR paid by these companies decreased from $23.6 \%$ in 2009 to $19.9 \%$ in 2010 and $16 \%$ in 2011. The study further notes that, at the end of 2009, United States companies had at least USD 1 trillion of foreign retained earnings and considers this as a clear indication of profit shifting practices put in place by United States based MNEs.

In November 2011, Citizen for Tax Justice (CTJ) and Institute on Taxation and Economic Policy (ITEP) released its report, which found the average ETR for all 280 companies was only $18.5 \%$ between 2008 and 2010. Between 2009 and 2010, the ETR for all 280 companies averaged only $17.3 \%$, less than half of the statutory $35 \%$ rate. The study asserts that over the past decade, companies have been extremely aggressive at avoiding state taxes by shifting profits not only offshore, but also from states that would tax them into states that don't. In addition, most states also provide their own set of business tax breaks or abatements beyond the federal ones, although these often involve taxes other than corporate income taxes. ${ }^{16}$

In February 2014, CTJ and ITEP published another Report on ETR, which in-

\footnotetext{
${ }^{13}$ See Avi-Yonah, R. and Y. Lahav (2011), The Effective Tax Rate of the Largest US and EU Multinationals, University of Michigan Law School, Program in Law \& Economics, Working Paper No. 41. https://repository.law.umich.edu/cgi/viewcontent.cgi?referer=https://cn.bing.com/\&httpsredir=1\&a $\underline{\text { rticle }=1150 \& \text { context=law econ current. }}$

${ }^{14}$ See Yorgason, D.R. (2009), Collection of data on income and other taxes in surveys of U.S. multinational enterprises, Bureau of Economic Analysis Paper prepared for the 4th Joint Session of the Working Group on International Investment Statistics, 8 October 2009.

https://www.bea.gov/research/papers/2009/collection-data-income-and-other-taxes-surveys-us-mul tinational-enterprises

${ }^{15}$ See Markle, K.S. and D.A. Hackelford (2011), Cross-country Comparisons of corporate income taxes, National Bureau of Economic Research Working Paper No. 16839, February 2011.
} 
dicated a number of key findings. As a group, the 288 corporations examined paid an effective federal income tax rate of just $19.4 \%$ over the five-year period far less than the statutory $35 \%$ tax rate. 26 corporations, including Boeing, General Electric, Priceline.com and Verizon, paid no federal income tax at all over the five-year period. A third of the corporations (93) paid an effective tax rate of less than ten percent over that period (McIntyre, et al., 2014). Of those corporations in the sample with significant offshore profits, two-thirds paid higher corporate tax rates to foreign governments where they operate than they paid in the U.S. on their U.S. profits. ${ }^{17}$

According to the CTJ report, 111 of the 288 companies paid zero or less in federal income taxes in at least one year from 2008 to 2012. The sectors with the lowest effective corporate tax rates over the five-year period were utilities (2.9\%), industrial machinery (4.3\%), telecommunications (9.8\%), oil, gas and pipelines (14.4\%), transportation (16.4\%), aerospace and defense (16.7\%) and financial (18.8\%). The tax breaks claimed by these companies are highly concentrated in the hands of a few very large corporations. Just 25 companies claimed $\$ 174$ billion in tax breaks over the five years between 2008 and 2012. That's almost half the $\$ 364$ billion in tax subsidies claimed by all of the 288 companies in the sample. Five companies-Wells Fargo, AT\&T, IBM, General Electric, and Verizon-enjoyed over $\$ 77$ billion in tax breaks during this five-year period ${ }^{18}$ (McIntyre et al., 2014).

Based on the above mentioned findings, CTJ refutes the prevailing view inside the Washington, D.C. Beltway that America's corporate income tax is more burdensome than the corporate income taxes levied by other countries, and that this purported (but false) excess burden somehow makes the U.S. "uncompetitive." 19

However, the business community tends to make opposite arguments against academics or independent advocates of tax justice. For instance, a study commissioned by the Business Roundtable, undertook by $\mathrm{PwC}$ in 2011 analyses the ETRs of the 2000 largest companies in 59 countries for the period 2006-2009 and concludes that U.S.-based companies face an average ETR of $27.7 \%$ compared to a rate of $19.5 \%$ for their foreign-headquartered counterparts. By country, ${ }^{16}$ Citizens for Tax Justice with the Institute on Taxation and Economic Policy (2011), Corporate Taxpayers and Corporate Tax Dodgers 2008-10, November 2011. https://www.ctj.org/wp-content/uploads/2017/11/CorporateTaxDodgersReport.pdf.

${ }^{17}$ See Robert S. McIntyre (2014), Matthew Gardner, Richard Phillips, “The Sorry State of Corporate Taxes: What Fortune 500 Firms Pay (or Don't Pay) in the USA And What they Pay Abroad 2008 to 2012”, February 2014. https://www.ctj.org/wp-content/uploads/2017/11/sorrystateofcorptaxes.pdf. ${ }^{18}$ See Robert S. McIntyre (2014), Matthew Gardner, Richard Phillips, “The Sorry State of Corporate Taxes: What Fortune 500 Firms Pay (or Don't Pay) in the USA And What they Pay Abroad 2008 to 2012", February 2014. https://www.ctj.org/wp-content/uploads/2017/11/sorrystateofcorptaxes.pdf. ${ }^{19}$ Responding to the corporate lobbyists' claim that "U.S. corporate tax rate is too high, and that it's not 'competitive' with the rest of the world," Robert McIntyre pointed out, "Our new report shows that both of these claims are false. Most of the biggest companies aren't paying anywhere near 35\% of their profits in taxes and far too many aren't paying U.S. taxes at all. Most multinationals are paying lower tax rates here in the United States than they pay on their foreign operations." https://www.ctj.org/wp-content/uploads/2017/11/sorrystateofcorptaxes.pdf 
U.S.-headquartered companies faced a higher worldwide ETR than their counterparts headquartered in 53 of the 58 foreign countries. The average ETR faced by U.S.-headquartered companies was more than $5 \%$ higher than the average ETR faced by companies headquartered in the other 28 OECD countries represented in the sample (22.6\%) during the 2006-2009 period. U.S. headquartered companies faced an average ETR more than $11 \%$ higher than the average ETR faced by companies headquartered in non-OECD countries (16.5\%) (PwC, 2011). The average ETR faced by U.S.-headquartered companies was $5.8 \%$ higher than the rate for companies headquartered in the $18 \mathrm{EU}$ countries represented in the sample $(21.9 \%){ }^{20}$

A Tax Foundation Study also demonstrates the similar position of the Business Roundtable. The study found that the U.S. has the second-highest statutory corporate income tax rate (39.2\%) in the developed world. This rate is only 0.35 percentage points behind OECD-leading Japan. Despite anecdotes regarding a few companies that exploit the dubious carve-outs in the tax code to minimize their tax liabilities, the results of 13 unique studies of the ETR on corporate investment across the globe show that the average U.S. corporate ETR, like the statutory rate, is nearly the highest in the world. By every available measure, the U.S. imposes a very high tax burden on its corporate sector, in comparison to other nations, even after credits and deductions are considered. The average corporate ETR for corporations headquartered in the U.S. is roughly $27 \%$, while the average of other nations is about $20 \%$. The average ETR for new investment in the U.S. is roughly $29.8 \%, 7.4$ point above worldwide competition. The U.S. corporate ETR consistently ranks among the five highest of nations considered. The only nation with a higher effective tax rate in each study is Japan, which not by coincidence is the only developed nation with a higher statutory rate than the U.S. ${ }^{21}$

According to PwC's another research project released in 2014, the average ETR from 2012 to 2013 have continued to edge upward for industrial products and automotive sectors, reflecting a modest rebound in the global business climate that is leading to increased profits at many companies. Despite a decline in ETR from 2012 to 2013, primarily driven by the impact of the American Taxpayer Relief Act of 2012, which reinstated R \& D credits and other U.S. tax extenders temporarily suspended in 2012, the average ETR for the global companies represented in PwC's analysis increased to 27.4\% between 2011 and 2013. The average ETR by country for profitable companies that paid taxes in each of the past three years remained constant or increased (with the exception of one country), even though a number of countries reduced their statutory tax rates. Countries at the lower end of the ETR range showed a steeper increase in the ETR over the three years than those at the higher end of the range. The study

\footnotetext{
${ }^{20}$ See PwC (2011), Global Effective Tax Rates, April, 2011. http://businessroundtable.org/sites/default/files/Effective_Tax_Rate_Study.pdf

${ }^{21}$ See Philip Dittmer, “Tax Foundation Special Report: U.S. Corporations Suffer High Effective Tax Rates by International Standards”, http://taxfoundation.org/sites/default/files/docs/sr195.pdf.
} 
posits that as companies expand global operations and take advantage of differences in country tax rates, this gap will narrow even further. (PwC US Issues, 2014) Tax incentives and credits remained the largest favorable driver of ETR in 2013, reported by 131 companies in PwC's report, which resulted in a benefit of $3.5 \%$ overall and $3.4 \%$ among U.S.-based companies. ${ }^{22}$

The U.S. Government Accountability Office (GAO) Report to Congressional Requesters of 2013 might be more objective, as GAO examined corporate tax returns to determine the taxes corporations actually pay. The Report found that in 2010, profitable U.S. corporations that filed a Schedule M-3 paid U.S. federal income taxes amounting to about $13 \%$ of the pretax worldwide income that they reported in their financial statements (for those entities included in their tax returns). When foreign and state and local income taxes are included, the ETR for profitable filers increases to around $17 \%$. The inclusion of unprofitable firms, which pay little if any tax, also raises the ETRs because the losses of unprofitable corporations greatly reduce the denominator of the measures. Even with the inclusion of unprofitable filers, which increased the average worldwide ETR to $22.7 \%$, all of the ETRs were well below the top statutory tax rate of $35 \% .{ }^{23}$

But the GAO finding was strongly attacked by the Business Roundtable, which argues that "American companies on average face one of the highest global effective tax rates in the world. U.S. companies in aggregate faced a worldwide effective tax rate in excess of 35\%, far higher than that found by GAO for 2010 . Even limiting the analysis to the three most recent years, companies with positive taxable income paid an average worldwide effective tax rate of more than $30 \%$. And as for the 2010 rates cited by GAO, it turns out they omitted most foreign taxes in their computation of the worldwide effective tax rate, dramatically understating the actual effective tax rate in that year (Miller, 2013). American companies face high statutory tax rates and high effective tax rates relative to their competitors from around the world. ${ }^{24}$

The critique of GAO from Business Roundtable heavily depends on the PwC study led by Andrew B. Lyon of PwC. ${ }^{25}$ He argued that GAO's May 2013 analysis of average corporate effective tax rates understated worldwide effective tax rates of U.S. corporations by primarily focusing on only 2010-when rates were distorted from the impact of losses and write-downs reported on financial statements during the recession in advance of their recognition for tax purposes-and by omitting foreign taxes paid on foreign income distributed as dividends to the U.S. corporations. That omission alone understated the worldwide ${ }^{22}$ See PwC US Issues 2014 Tax Rate Benchmarking Study for Industrial Products and Automotive Sectors",

https://www.prnewswire.com/news-releases/pwc-us-issues-2014-tax-rate-benchmarking-study-forindustrial-products-and-automotive-sectors-261966241.html.

${ }^{23}$ United States Government Accountability Office Report to Congressional Requesters, "CORPORATE INCOME TAX: Effective Tax Rates Can Differ Significantly from the Statutory Rate", May 2013. http://www.gao.gov/assets/660/654957.pdf.

${ }^{24}$ See Matthew M. Miller (2013), "Analysis Shows GAO Got It Wrong on the Corporate Effective Tax Rate”, Oct 22, 2013.

http://businessroundtable.org/media/blog/analysis-shows-the-gao-got-it-wrong-on-the-corporate-e ffective-tax-rat. 
effective tax rate of corporations by 4 to 5 percentage points in 2010 (Lyon, 2010). Extending the GAO analysis to the 2004-2010 period, the average current worldwide effective tax rate for all U.S. corporations exceeded 35\%. ${ }^{26}$

However, Andrew B. Lyon' criticism was rebutted by CTJ. The PwC study finds that worldwide profits (not just U.S. profits) were subject to worldwide taxes (including U.S. federal and state taxes plus foreign taxes) of $22 \%$. The effective worldwide tax rate can be expected to be slightly higher than the effective U.S. tax rate that CTJ calculated because the CTJ study also found most of the corporations to pay higher taxes in the other countries where they did business, and because the worldwide rate includes state corporate taxes. However, PwC's report also includes two other, odd measures of corporate tax rates that are irrelevant to the policy debate, and tries to get reporters to focus on these irrelevant figures. One includes companies whether they were profitable are not in the years examined. Of course, corporations that are not profitable are not expected to pay the corporate income tax, which is a tax on profits. But including corporations with losses reduces the total amount of profits and makes the effective tax rate (taxes as a percentage of profits) appear much larger. Another irrelevant measure used by the $\mathrm{PwC}$ study includes all corporations with positive taxable income. This measure leaves out corporations that actually are profitable but avoid taxes because of breaks (like depreciation breaks) that reduce their taxable income to below zero (CTJ Staff, 2013). This measure simply excludes the corporations that are most effective at dodging taxes. ${ }^{27}$

Bruce Bartlett endorsed the argument of GAO and CTJ. "The exclusion of foreign taxes is not significant, because American companies get a $100 \%$ credit for all foreign taxes paid against their tax liability in the U.S. Including companies with losses raises the aggregate effective tax rate by reducing aggregate profits. Thus the losses of those that paid no taxes are in effect attributed to profitable companies, making their tax burden appear higher by shrinking their measured profits while their taxes are unchanged. In Bartlett's opinion, the debate is highly technical, involving accounting concepts on which there is legitimate discussion (Bartlett, 2013). There is also a data problem, because corporate tax returns are private, just as individual returns are. ${ }^{28}$

Independent economist Martin A. Sullivan pointed two issues about the methodology of GAO Report. To arrive at its $12.6 \%$ figure, the GAO divided total U.S. tax liability reported on Form 1120 ( $\$ 181.4$ billion) by pretax book income (\$1.44 trillion). To arrive at its $16.9 \%$ figure, it added current state and local tax

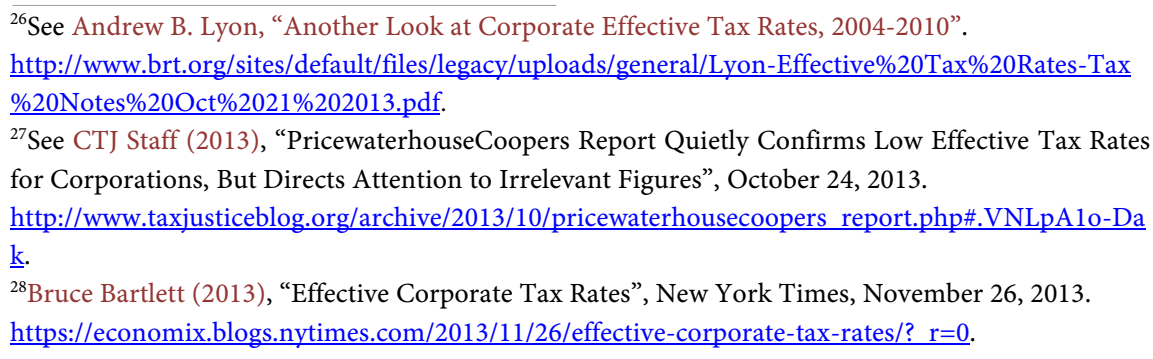


expense, current foreign tax expense, and foreign withholding taxes to the numerator. The low GAO figure for foreign tax liability is attributable to the fact that Schedule M-3 data do not include the taxes paid by foreign subsidiaries (which are not includable on federal tax returns). The GAO's pretax income in the denominator excludes deferred income of foreign subsidiaries. The absence of information about subsidiary taxes and profits means that ETRs computed with Schedule M-3 data are missing one of the most important aspects of their world-wide tax picture. Without the missing data, it is impossible to say if a truly worldwide ETR would be above or below the $16.9 \%$ reported by the GAO. The second reason for the GAO's low effective tax rate for 2010 is that the effects of a recession are more dominant in 2010 than they are in other studies, which include both recession and non-recession years or no recession years at all. In 2010, the U.S. economy was still severely hobbled by the Great Recession, corporate tax liabilities reported on tax returns used in the numerator of the GAO's effective tax rates were extraordinarily low in that year, and the tax liability reported on tax returns as a percentage of total pretax corporate profits as reported by the Commerce Department in the National Income and Product Accounts was approximately $17 \%$. A large part of the drop in tax liability as recorded on tax returns as a percentage of profits is likely due to bonus depreciation available in that year. The average for the prior 10 years was approximately $25 \%$, and in none of those years did the percentage go below $20 \%$. Based on the reasonable assumption that total liability reported on tax returns is roughly proportional to liability of corporations with more than $\$ 10$ million in assets, the GAO estimated that ETR would have been approximately 8 percentage points higher if estimates were made for a year that was not affected by a large recession. In conclusion, Sullivan believes it is reasonable not to revise the consensus view that average world-wide corporate ETRs are somewhere in the mid-or upper 20s when we are not in the throes of a recession..$^{29}$

Sullivan also warns the misleading ETR calculations from advocacy groups. As mentioned earlier, the Business Roundtable concludes by calculating a corporate ETR for 2009 of 33\%, and argues that the figure would be closer to $35 \%$ if it had included business tax credits such as the research credit. This implies that there are no significant tax breaks in the code and that no tax planning takes place. But the Business Roundtable's method of calculating an ETR would produce a number close to $35 \%$, whether or not there was massive tax avoidance taking place. In the current environment, in which domestic tax credits are a relatively small part of the tax picture, it provides no useful information about the corporate tax burden. Its numerator is tax liability paid plus most tax credits. Its denominator is taxable income. The former as a percentage of the latter will almost always be approximately equal to the statutory rate. ${ }^{30}$

\footnotetext{
${ }^{29}$ See Martin A. Sullivan, "Behind the GAO's 12.6 Percent Effective Corporate Rate”, http://taxprof.typepad.com/files/140tn0197.pdf.

${ }^{30}$ See Martin A. Sullivan, "Behind the GAO's 12.6 Percent Effective Corporate Rate", https://taxprof.typepad.com/files/140tn0197.pdf.
} 
In the Nov. 25 issue of Tax Notes magazine, the GAO economists who conducted the original study acknowledged that averaging their results over several years and including foreign taxes, as Mr. Lyon did, would raise the effective tax rate to $22.9 \%$. The remaining difference between their study and the Lyon study results from the inclusion of companies with losses. ${ }^{31}$

The different and even apparently opposite research findings on the ETR in the U.S indicates that it is still an open questions on the exact ETR existing in the U.S.-based MNEs. Therefore, OECD BEPS Report is not satisfied with the current research findings. "Available studies on the ETRs of MNEs are useful, but there are hardly two studies using the same methodology. The use of different methodologies to calculate ETRs (in particular backward-looking ones) and shortcomings in the available data result in very divergent conclusions regarding the level of taxation imposed on MNEs and the prevalence of BEPS behaviors. Studies in relation to the same country or region arrive at very different, and in some cases opposite, results" (Bartlett, 2013)..$^{32}$

In fact, the researchers have different core values, commercial and political positions, methodologies and data. In some cases, the core values and political positions are more influential than the methodology and data. That partly explains why the lobbyist groups and progressive groups have totally opposite conclusions. Therefore, none of the findings is absolutely right or wrong. In other words, the diversified findings do not necessarily imply that every finding is ungrounded and invalid. In fact, each and every finding has its own merit and validity on certain point from certain perspective. As the blind men touching different part of the elephant may reach different conclusions, the research conclusions are also valid at least to some extent. Of course, the different but partly valid conclusions need to be integrated to reflect the full picture of the magnitude of the BEPS issue.

Despite the differences, there are also many commonalities in most of the studies. For instance, except for the study of the Business Roundtable/PwC, the Enterprise Institute and Tax Foundation, most researcher agree that the statutory corporate income tax rate (35\%) in the U.S. is one of highest in developed countries, while the average ETR is significantly lower than the statutory tax rate. Most researchers agree to reduce the higher statutory, in order to eliminate the motivation of the BEPS schemes.

Of course, average ETR is not a panacea indicator of BEPS. ETR especially average ETRs are always too general, ambiguous and even misleading. The reason is that ETRs result from a great number of factors, such as the coherence and enforceability of the legislation, the competence of the tax administrations and the ability of the MNEs' wisdom of tax planning including BEPS schemes. As the lower ETR is the single result triggered by three or even more contributing factors, it is not easy to identify and evaluate three different weights of the intention ${ }^{31}$ See Bruce Bartlett (2013), "Effective Corporate Tax Rates”, New York Times, November 26, 2013. https://economix.blogs.nytimes.com/2013/11/26/effective-corporate-tax-rates/?_r=0.

${ }^{32}$ For the data, see, Addressing Base Erosion and Profit Shifting (C) OECD 2013, P. 21. 
and quality of institutional arrangement (e.g. generous tax allowances) the enforcement competence of the tax administration (e.g. lax execution) and the tax planning strategies of MNEs in yielding the difference between the headline rate and ETR.

Furthermore, every factor conflates a set of complicated and correlated subcategories. For instance, there are various tax base rules that could produce profound impacts on the determination of the corporate taxable income, including but not confined to narrowly or broadly defined tax allowances deducted against the base and the timing rules on the acceleration of depreciation of capital costs for tax purposes relative to book/accounting or economic depreciation. For another instance, the different levels of expertise of tax planning consulting could also make difference in minimizing corporate tax of the MNEs.

Anyway, consistently measured ETRs could in principle provide useful indications of whether BEPS is indeed taking place. The relevance of ETR to BEPS schemes should not be denied just because of the existence of other contributing factors influencing the ETR. The reason is very simple. The MNEs have more resources to minimize their ETR by and thorough BEPS schemes. The common sense knowledge is that in most circumstances, the MNEs have more motivations than the legislature or the tax administrations to escape or reduce their tax burden by reducing the corporate tax base.

For the purpose of achieving more scientific research findings, it is necessary for the OECD and the international community to innovate the methodology and to update the data with the assistance of the Automatic Exchange of Information (AEOI) standard that the OECD has developed with all G20 countries. ${ }^{33}$ Anyway, the shortcomings of the current research projects are unable to block the process of anti-BEPS efforts worldwide. The current research findings are already sufficient to mandate the international community to innovate the international tax law philosophy and work out fair and effective anti-BEPS framework and mechanism as soon as possible.

\subsection{The Ratio of Corporate Tax Revenue in GDP Has Not Synchronously and Substantially Increased in the Process of Globalization}

Across the OECD ocuntries, corporate income tax raises revenues equivalent to around $3 \%$ of GDP or about $10 \%$ of total tax revenues. Although their relative importance varies from country to country, corporate income tax receipts constitute an important component of government revenues. ${ }^{34}$

The BEPS Report seems to be satisfied with the ratio of corporate income tax in GDP. "Generally, revenues from corporate income taxes as a share of GDP have increased over time, with the unweighted average of revenues deriving ${ }^{33}$ The imminent implementation of AEOI is pushing up voluntary disclosures by tax evaders which have already yielded 37 billion euros of additional revenue in around 25 OECD and G20 countries that have put in place these initiatives. See, OECD SECRETARY-GENERAL REPORT TO THE G20 LEADERS, Brisbane, Australia, November 2014.

${ }^{34}$ Addressing Base Erosion and Profit Shifting (C) OECD 2013, P. 15-P. 20. 
from taxes on corporate income as a percentage of GDP increasing from $2.2 \%$ in 1965 to $3.8 \%$ in 2007. This positive trend reversed in 2008 and 2009, when the average ratio dropped to $3.5 \%$ and $2.8 \%$, respectively. It recovered slightly in 2010, to $2.9 \% .{ }^{35}$

However, the authors of the BEPS Report are not quite confident about their research findings and the figures they cited. "Although they may provide useful indications, these trends in the relationship of corporate income tax to GDP do not necessarily imply either the existence or non-existence of BEPS practices" ${ }^{36}$

Although I appreciate the citation of the data on the ratio of corporate income tax in the GDP in the BESPS Report, I disagree with their conclusion and the interpretation of the data cited by the Report. The major reason is that the BEPS researchers should not be satisfied with the stable ratio of corporate income tax in GDP. The BEPS schemes must exist behind the phenomenon of the stable maintenance or slight increase of corporate income tax. It is well known that the globalization has greatly benefited the MNEs. The MNEs are the largest beneficiary in the process of globalization. Therefore, the contribution of corporate income tax to GDP is supposed to be progressively growing in the process of legislation.

The fact is that the corporate income tax as a percentage of GDP in OECD countries only increased from $2.25 \%$ in 1965 to $3 \%$ in $2011^{37}$, and that the ratio during the period of 1990-2011 has not been substantially increased. For instance, the ratio in the U.S. was 2.4 in 1990, 3.4 in 2006, but only 2.6 in 2011. The ratio in the France was 2.2 in 1990, 3.4 in 2001, but only 2.5 in 2011. The ratio in the Germany was 1.7 in both 1990 and 2011. ${ }^{38}$

In some countries, the ratio of the corporate tax revenue of GDP during the period of 1990-2011 has been dropped significantly. For example, the ratio in Japan dropped from 6.4 in 1990 to 3.3 in 2011, the ratio in the Netherlands dropped from 3.2 in 1990 to 2.2 in 2010, the ratio in UK dropped from 3.5 in 1990 to 2.8 in $2011 .^{39}$

The ratio in the U.S. is also not very optimistic. According to GAO Report, corporate income tax revenues fell from the 1960s to the early 1980s for several reasons. For example, corporate income became a smaller share of GDP during these years, partly due to the fact that corporate debt, and therefore deductible interest payments, increased relative to corporate equity, reducing the tax base. In addition, tax expenditures, such as more generous depreciation rules also grew over that period. Since the early 1980s, the corporate income tax has accounted for about $6 \%$ to $15 \%$ of federal revenue. Relative to GDP, the corporate income tax has ranged from a little over $1 \%$ to just under $2.7 \%$ during those same years. The Congressional Budget Office $(\mathrm{CBO})$ projected that despite the

\footnotetext{
${ }^{35}$ Addressing Base Erosion and Profit Shifting (c) OECD 2013, P. 15.

${ }^{36}$ Addressing Base Erosion and Profit Shifting (C) OECD 2013, P. 16.

${ }^{37}$ Source: OECD (2012), Revenue Statistics 1965-2011.

${ }^{38}$ For the data, see, addressing Base Erosion and Profit Shifting (C) OECD 2013, P. 58-p .59.

${ }^{39}$ For the data, see, addressing Base Erosion and Profit Shifting (C) OECD 2013, P. 58-p. 59.
} 
recent uptick, corporate income tax revenue for the next 10 years as a percentage of GDP is expected to stay within this same range. ${ }^{40}$

The situation of U.S. is considered as a problem by some authors. The reason is that 2010 was a good year for U.S. corporations, with profits very close to their pre-recession level and about a third higher than the boom years of the 1990s. In Figure 1 Since 2010, profits have increased by another percentage point of GDP. But aggregate corporate taxes in 2010 were low, just $1.3 \%$ of GDP, because corporations can carry forward losses from previous years to offset taxes in future years (Bartlett, 2013). Since many corporations had huge losses in 2008 and 2009, because of the economic recession, this reduced their tax liability in 2010 below the long-term trend of about $2 \%$ of GDP. ${ }^{41}$

Noticeably, a small number of countries, especially the five Nordic countries witnessed the increasing percentage of the corporate tax revenue of GDP during the period of 1990-2011 (Bartlett, 2013). For instance, the ratio in Norway increased from 3.7 in 1990 to 11.0 in 2011, the ratio in Denmark increased from 1.7 in 1990 to 2.8 in 2011, the ratio in Finland increased from 2.0 in 1990 to 2.7 in 2011, the ratio in Sweden increased from 1.6 in 1990 to 3.5 in 2011, the ratio in Iceland increased from 1.6 in 1990 to 2.3 in $2011 .{ }^{42}$ In fact, except for the case of Norway, the increase of the ratio in other Nordic countries is not dramatic.

Therefore, the ratio of corporate income tax in GDP has not necessarily increased in every OECD country. Even the maintenance or slight increase of the ratio of corporate income tax in GDP result from many diversified tax payers especially the domestic corporations, and multiple contributing factors. The BEPS Report also contributed the maintenance of corporate tax revenues to two major factors. The first one is base-broadening measures, such as aligning depreciation for tax purposes more closely with actual depreciation, and reductions in tax expenditures. The second factor is increased business profits and incorporation. ${ }^{43}$ Without distinguishing and establishing the different factors stabilizing or increasing the corporate income tax base in each jurisdiction, it is unfair to contribute the stable or slight increase of corporate income tax to the generous tax paid by the MNEs.

Again, the unweighted average of taxes on corporate income as a percentage of total taxation in OECD countries during the period of 1965-2010 has not significantly increased. The ratio was $8.8 \%$ in 1965 , dropped to $7.6 \%$ in 1975 , increased to $10.6 \%$ in 2007. Starting from 2008, likely due to the economic downturn,

\footnotetext{
${ }^{40}$ United States Government Accountability Office Report to Congressional Requesters, "CORPORATE INCOME TAX: Effective Tax Rates Can Differ Significantly from the Statutory Rate", May 2013. http://www.gao.gov/assets/660/654957.pdf.

${ }^{41}$ Bruce Bartlett (2013), “Effective Corporate Tax Rates”, New York Times, November 26, 2013. https://economix.blogs.nytimes.com/2013/11/26/effective-corporate-tax-rates/?_r=0 .

${ }^{42}$ Bruce Bartlett (2013), “Effective Corporate Tax Rates”, New York Times, November 26, 2013. https://economix.blogs.nytimes.com/2013/11/26/effective-corporate-tax-rates/?_r=0.

${ }^{43}$ For the data, see, Addressing Base Erosion and Profit Shifting @ OECD 2013, P. 17.
} 


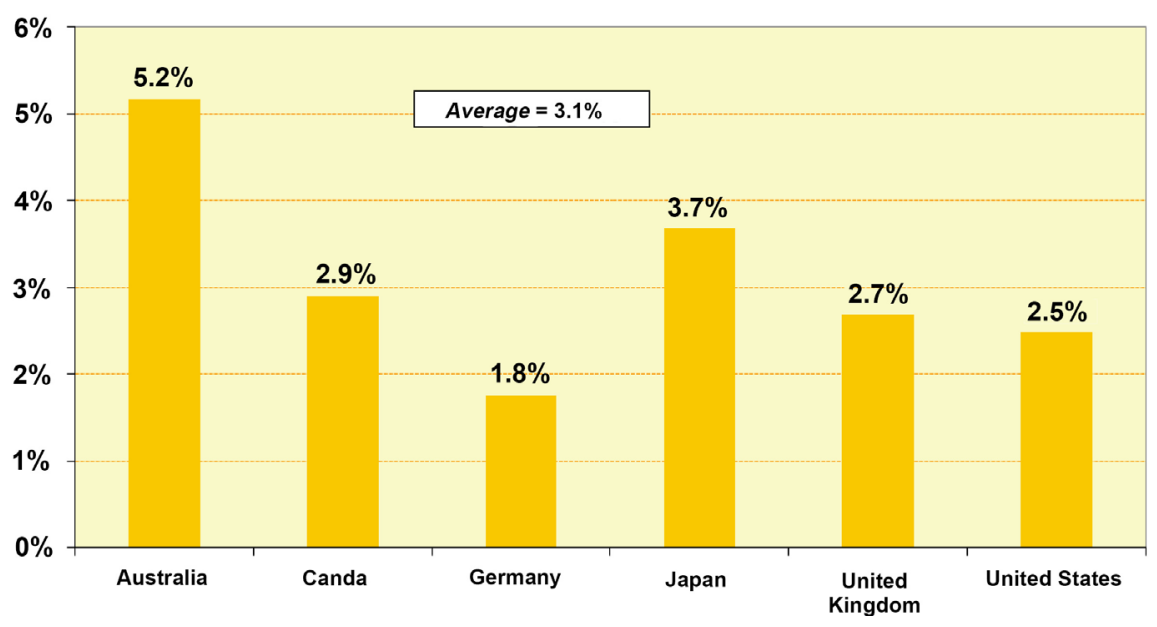

Figure 1 Corporate tax revenue as percentage of GDP, 2012. Source: Organization for Economic Cooperation and Development, OECD Revenue Statistics 2014, Table 11, p. 98.

the ratio declined to $10 \%$ in 2008 and $8.4 \%$ in 2009 ; subsequently it increased to $8.6 \%$ in $2010 .{ }^{44}$

As the OECD BEPS Report only collected the data from 31 countries, my analysis is only valid on the limited data. Many developing countries especially the BRICS countries were not included in this Report. Anyway, it is fair to say that the growing MNEs have not paid their fair share of tax in commensurate with their growth on the international stage. Although the corporate income tax is paid by both domestic firms and MNEs, given the fact that the MNEs are the largest beneficiary of rapid globalization process, the MNEs failed in demonstrating their substantial contribution of tax to the GDP progressively.

\subsection{The Relevance of the FDI Flows to BEPS}

The active international capital movements are going hand in hand with the aggressive BESP schemes of MNEs. Without the combined use of inward and outward investments, it is impossible for the MNEs to achieve the success of BEPS schemes. Therefore, the data on the direction and the magnitude of the international investment serves as a very useful indicator of the existence and magnitude of BEPS. The sudden arising waves in the quite and calm ocean always imply the jumping of sharks or crocodiles under the water.

The IMF and OECD have gathered some data to monitor the global foreign investment. Foreign investment could be classified as foreign direct investment (FDI) and foreign portfolio investment (FPI). According to the 4th Edition of the OECD Benchmark Definition of Foreign Direct Investment, FDI is a category of investment that reflects the objective of establishing a lasting interest by a resident enterprise in one economy (direct investor) in an enterprise (direct investment enterprise) that is resident in an economy other than that of the direct investor. The lasting interest implies the existence of a long-term relationship between the direct investor and the direct investment enterprise and a significant ${ }^{44}$ For the data, see, Addressing Base Erosion and Profit Shifting (c) OECD 2013, P. 16. 
degree of influence on the management of the enterprise. The direct or indirect ownership of $10 \%$ or more of the voting power of an enterprise resident in one economy by an investor resident in another economy is evidence of such a relationship. While in the case of portfolio investment, investors do not generally expect to influence the management of the enterprise.

The IMF Co-ordinated Direct Investment Survey (CDIS) indicates that in 2010 three notorious tax heavens including Barbados, Bermuda and the British Virgin Islands received more FDIs (combined $5.11 \%$ of global FDIs) than Germany $(4.77 \%)$ or Japan $(3.76 \%)$. During the same year, these three jurisdictions made more investments into the world (combined 4.54\%) than Germany $(4.28 \%)^{45}$

According to CDIS Survey of 2013, the British Virgin Islands were the second largest investor into China (14\%) after Hong Kong (48\%) and before Japan (6\%). The other top ten investor were Singapore (4\%), the United States (3\%), Korea (3\%), Cayman Island (2\%), Germany (2\%), Samoa (1\%) and Taiwan, China $(1 \%)$.

According to CDIS Survey of 2013, out of $\$ 2.763956$ trillion of inward direct investment in the U.S., the Netherlands was the third largest investor (10\%), second to UK (19\%) and Japan (12\%). Out of \$4.660906 trillion of outward direct investment from the U.S., the top five investor were the Netherlands (16\%), UK (12\%), Luxembourg (9\%), Canada (8\%) and Bermuda (6\%).

Fortune 500 U.S. Companies have set up their 2013 subsidiaries in their twenty favorite tax havens or tax preferred jurisdictions, including the Netherlands, Singapore, Hong Kong, Luxembourg, Cayman Islands, Switzerland, Ireland, Bermuda, Mauritius, British Virgin Islands, Costa Rica, Barbados, Panama, Cyprus, Channel Islands, Bahamas, Gibraltar, Bahrain, Malta, Macau ${ }^{46}$ (Phillips et al., 2014).

Out of \$1.60797 trillion of inward direct investment in the UK, Switzerland was the third largest investor (4\%), second to U.S. (24\%) and Japan (5\%), Cayman Islands and Guernsey were both top four investor (1\%). Out of \$1.552929 trillion of outward direct investment from the UK, Luxembourg was the largest destination (12\%), Luxembourg received 9\%, Bermuda received 6\%.

Out of $\$ 926.532$ billion of inward direct investment in Germany in 2013, the Netherlands was the largest investor (22\%), Luxembourg was the second largest (17\%), and Switzerland was the five largest (6\%). Out of $\$ 1.43594$ trillion of outward direct investment from Germany, Luxembourg was the third largest destination (9\%), the Netherlands was the top four destination (8\%).

There are also very active and substantial inward and outward direct investments between and among the tax heavens. According to CDIS Survey of 2013, out of \$4.342358 trillion of inward direct investment in the Netherlands, Luxembourg was the second largest investor (16\%), only second to U.S. (23\%), ${ }^{45}$ For the data, see, addressing Base Erosion and Profit Shifting (C) OECD 2013, P. 17.

${ }^{46}$ Richard Phillips (2014), Steve Wamhoff, and Dan Smith, Offshore shell games 2014: The use o1 offshore tax heavens by fortune 500 companies, by Citizens for Tax Justice (CTJ). 
Bermuda was the fourth largest investor (6\%), same with Germany (6\%). Out of $\$ 5.217111$ trillion of outward direct investment from the Netherlands, Luxembourg was the third largest destination (11\%), Switzerland was the fourth largest (7\%), larger than Germany (6\%).

Among \$1.196301 trillion of inward direct investment in Hong Kong in 2013, the top five investor were BVI (37\%), Mainland China (30\%), the Netherlands (7\%), Bermuda (6\%), U.S. (4\%). Out of $\$ 1.075549$ trillion of outward direct investment from Hong Kong, the top five destinations were Mainland China (44\%), BVI (37\%), Bermuda (4\%), UK (3\%) and Cayman Islands (2\%).

In the case of $\$ 750.078$ billion of inward direct investment in Singapore in 2013, the top five investor were U.S. (13\%), the Netherlands (9\%), BVI (8\%), Japan (7\%) and Cayman Islands (6\%).

Although the available FDI data is unable to reflect the individual, actual intentions and behaviors of BEPS schemes, but is sufficient to identify most popular tax heavens favored by the MNEs for the purpose of BEPS schemes, and to confirm the increasing segregation between the jurisdiction of value creation and investment and the jurisdiction of profit report. The inbound and outbound FDI between and among tax heavens and jurisdictions of residence and jurisdictions of source, especially the FDI between and among the tax heavens are strong evidence of the magnitude of the BEPS schemes to some extent. Of course, the BEPS scheme is unable to make success without the complicated conduit structures.

\subsection{The Relevance of the Widespread Conduit or SPE Structures to BEPS Schemes}

According to the 4 th Edition of the OECD Benchmark Definition of Foreign Direct Investment, a conduit is an enterprise that obtains or borrows funds, often from unaffiliated enterprises, and remits those funds to its direct investor or another affiliated enterprise. Some conduits and holding companies may have a substantial physical presence as evidenced by office building, equipment, employees, etc. Others may have (little) or no physical presence and may exist only as shell companies.

The 4th Edition of the OECD Benchmark Definition of Foreign Direct Investment defines the terminology "SPE" as an enterprise if it meets the following criteria: "1) The enterprise is a legal entity, a) formally registered with a national authority; and b) subject to fiscal and other legal obligations of the economy in which it is resident. 2) The enterprise is ultimately controlled by a non-resident parent, directly or indirectly. 3) The enterprise has no or few employees, little or no production in the host economy and little or no physical presence. 4) Almost all the assets and liabilities of the enterprise represent investments in or from other countries. 5) The core business of the enterprise consist of group financing or holding activities, that is viewed -from the perspective of the compiler in a given country the channelling of funds from non-residents to other non-residents. However, in its daily activities, managing and directing plays 
only a minor role".

Despite the minor differences between "conduit" and "SPE", "conduit" and "SPE" sometimes are used without restrict differentiation in the practice and research works. The MNEs usually use the conduits or special purpose enterprises or entities (SPEs) to channel investments and intra-group financing from one jurisdiction to another, in order to escape or reduce the tax on dividends and interest during the course of the investment and the tax on capital gains upon exit. Most of the conduits or SPEs are located in the tax heavens.

One of most frequently cited case is the Ugland House. This House is a modest five-story office building in the Cayman Islands, yet it is the registered address for 18,857 companies. ${ }^{47}$ In this office building, the vast majority of companies have no physical presence in the Caymans other than a post office box. About half of these companies have their billing address in the U.S., even while they are officially registered in the Caymans. ${ }^{48}$

Conduits or SPEs are not only incorporated in the Cayman Islands, but also incorporated in many other notorious tax havens, including but not confined to Bermuda, British Virgin islands, Bahamas, Luxembourg, Ireland, Netherlands Antilles, the Netherlands, Cyprus, Barbados, Singapore, Switzerland, Costa Rica, Panama, Mauritius, Jordan and Malta. Despite the different legal environments in these jurisdictions, their common characteristic is very low or nonexistence taxes for the corporations including the MNEs. That is why they are called tax havens.

If the MNEs have substantial trade or investment in the tax havens, it is unfair to blame either the tax havens or the MNEs, as every jurisdiction has the tax sovereignty to craft its own taxation regime to attract foreign investment, every MNE has the freedom of establishment in any jurisdictions they prefer in the global economy. However, the ironical thing is that an international company or business with no links to tax havens is a rare species nowadays. ${ }^{49}$

In other words, although most MNEs do not have real and substantial workforce, capital investment, consumer market, head quarter or development and research center in the tax havens, and do not generate any genuine and substantial revenues in the boundary of the tax havens, most MNEs are willing to disguise their profits generated in other jurisdictions as the foreign profits made in tax havens for the purpose of tax avoidance. In short, the SPEs or shell corporations registered in the tax haven are merely the instruments for the MNEs to implement the BEPS schemes.

For instance, the Netherlands has hosted many debt-issuing SPEs. In addition, several case studies provide examples of tax avoidance via Dutch SPEs. In the Netherlands, six types of SPE account for approximately $80 \%$ of total SPE assets. The main type is an intra-group financing company and not a plain intermediate ${ }^{47}$ Governments Accountability Office, "Business and Tax Advantage Attract U.S. Persons and Enforcement Challenges Exists", GAO-08-778. http://www.gao.gov/highlights/d08778high.pdf ${ }^{48} \mathrm{Id}$.

${ }^{49}$ Ronen Palan, Richard Murphy, and Christian Chavagneux, Tax Havens How Globalization Really Works, by Cornell University Press, 2010, p 7. 
holding. Many SPEs combine holding activities with other intra-group financing arrangements, such as long-term on-lending or taking deposits and providing short-term loans within the group. The second-largest type is plain intermediate holdings constitute. Together, these three FDI diversion types account for approximately $40 \%$ of SPEs and almost $60 \%$ of total SPE assets. The fourth type is the mixed financing companies, which represent the largest SPE type with external funding. Considering that this is a rather broad type, its $13 \%$ share in total assets is relatively modest and confirms that most SPEs have a more specific capital structure. The fifth type is separate fund raising vehicles form a somewhat smaller category with $8 \%$ of total assets. The sixth type is securitization vehicles, which accounts for a very small fraction of total assets only (Weyzig, 2013). This may be an underestimate, because securitization vehicles are probably underrepresented in the monthly reporting population of large SPEs due to their relatively small size. ${ }^{50}$

The remaining SPEs, representing approximately $20 \%$ of total assets, do not fit into the six categories defined above and hold more than 20\% non-FDI assets. These SPEs probably include treasury companies of foreign multinationals that hold large liquidity reserves, as well as leasing and re-invoicing SPEs (Weyzig, 2013). They may also include SPEs that directly hold foreign real estate, which is not included in the FDI data. ${ }^{51}$

Although the use of SPEs does not automatically imply that they only serve for BEPS purposes, in depth analysis of the data on SPE structures will help to pierce the BEPS veil of the MNEs. The excessive use of conduits or SPEs in tax heavens is the key instrument in disconnecting the location where value creating activities and investment take place and the location where profits are reported for tax purposes.

\subsection{The Magnitude of BEPS Schemes of U.S.-Based MNES}

There are even more intensive studies on the magnitude of BEPS schemes of U.S.-based MNEs, in addition to the studies on the ETR of the U.S.-based MNEs.

Profit shifting from high tax countries to tax havens have generated a huge revenue loss in many source countries and have aroused a wide concern all over the world (Keightley, 2013). For example, U.S.-based MNEs reported earning $\$ 938$ billion in profit overseas in $2008 .^{52}$ Economist Kimberley A. Clausing estimated profit shifting cost the government between $\$ 57$ billion and $\$ 90$ billion in lost revenue in the same year. ${ }^{53}$

\footnotetext{
${ }^{50}$ See Francis Weyzig (2013), "International finance and tax avoidance via Dutch Special Purpose Entities", Paper for presentation at research seminar, Radboud University Nijmegen, 21 October 2013.

${ }^{51}$ Francis Weyzig (2013), "International finance and tax avoidance via Dutch Special Purpose Entities”, Paper for presentation at research seminar, Radboud University Nijmegen, 21 October 2013.

${ }^{52}$ U.S. Department of Commerce, Bereau of Economics Analysis: U.S. Direct Investment Abroad: Operations of U.S. Parent Companies and Their Foreign Affiliates (Revised 2008 Statistics), November 2011. http://www.bea.gov/scb/account articles/international/iidguide.htm.

${ }^{53}$ See Mark P. Keightley (2013), An Analysis of Where American Companies Report Profits. Indications of Profits shifting, January 18, 2013.
} 
For the purpose of avoiding taxation, U.S.-MNEs usually set subsidiary companies in tax havens. According to the report of Citizens for Tax Justice (CTJ), ${ }^{54}$ at least 362 companies, making up 72 percent of the Fortune 500, maintain 7827 subsidiaries in offshore tax havens as of 2013. The 30 companies collectively operate 1357 subsidiaries in tax havens for tax purpose. Specifically speaking, Bank of America, Citigroup, JP Morgan-Chase, AIG, Goldman Sachs, Wells Fargo and Morgan Stanley disclosed a combined 702 subsidiaries in tax havens.

All top twenty American corporations have their tax haven subsidiaries. Bank of America Corporation has 264 subsidiaries scattered in 13 tax havens and ranked No.1. AES corporation and Morgan Stanley both ranked No. 2 with 226 subsidiaries separately, followed with KKR (157), Thermo Fisher Scientific (144), PepsiCo (137), Merck (131), Pfizer (128), Marsh \& McLennan (110), Illinois Tool Works (105), Liberty Global (104), Stanley Black \& Decker (98), Marriott International (97), National Oilwell Varco (94), Dow chemical (93), Ecolab (91), Emerson Electric (86), Jp Morgan Chase \& Co (83), Mondelez International(83) and Abbott Laboratories (79), totaling 2536 subsidiaries all together ${ }^{55}$ (Phillips, et al., 2014).

The reason for so many U.S.-based MNEs choose to set up subsidiaries in tax havens, is that Under the U.S. tax system, even though the overseas profits produced by foreign subsidiaries of U.S. corporations are subject to U.S. tax, the tax is deferred until that overseas profits is repatriated to the US, namely paid as a dividend to the U.S. parent corporation. The purpose of this rule is to avoid double taxation of the MNEs. However, many greedy MNEs abuse this rule, make use of the loopholes of tax law, and disguise the profit made in U.S. as "foreign profit" earned by a subsidiary in tax havens, therefore avoiding to pay the tax to U.S.

The disguised offshore profits are shocking. In 2013, Apple held $\$ 111.3$ billion offshore, owed $\$ 36.4$ billion in US tax. General Electric reported held $\$ 110$ billion offshore. Microsoft held $\$ 76.4$ billion offshore, and owed $\$ 24.4$ billion in US tax. Pfizer officially holds $\$ 69$ billion in profits offshore for tax purposes, the third highest among the Fortune 500. Bank of America reports holding \$17 billion offshore and owed $\$ 4.3$ billion in US tax. PepsiCo reported holding $\$ 34.1$ billion offshore. The top 30 companies held $\$ 1199.9$ billion offshore, accounting for 62 percent of the offshore cash. ${ }^{56}$ (Phillips, et al., 2014)

Cash booked offshore for tax purposes by U.S. MNEs doubled between 2008 and 2013. An April 2014 study by research firm Audit Analytics found that the Russell 1000 list of U.S. companies collectively reported having just over \$2.1 trillion held offshore (Audit Analytics, 2014). That is nearly double the income re-ported offshore in 2008. ${ }^{57}$ The 287 Fortune 500 Companies that report off54“Offshore shell games 2014: The use of offshore tax heavens by fortune 500 companies". ${ }^{55}$ See Richard Phillips (2014), Steve Wamhoff, and Dan Smith, Offshore shell games 2014: The use of offshore tax heavens by fortune 500 companies, by Citizens for Tax Justice (CTJ).

${ }^{56}$ See Richard Phillips (2014), Steve Wamhoff, and Dan Smith, Offshore shell games 2014: The use of offshore tax heavens by fortune 500 companies, by Citizens for Tax Justice (CTJ).

${ }^{57}$ See Audit Analytics, “Overseas Earnings of Russell 1000 Tops \$2 Trillion in 2013,” 1 April 2014. https://blog.auditanalytics.com/overseas-earnings-of-russell-1000-tops-2-trillion-in-2013/. 
shore profits collectively hold $\$ 1.95$ trillion offshore, with the top 30 companies accounting for 62 percent of the total. More importantly, evidence indicates much of offshore profits are booked to tax havens ${ }^{58}$ (Phillips, et al., 2014).

According to the research findings of Congressional Research Service, American MNEs collectively reported 43 percent of their foreign earnings in five small tax haven countries: Bermuda, Ireland, Luxembourg, the Netherlands, and Switzerland in 2008. Yet these countries accounted for only 4 percent of the companies' foreign workforce and just 7 percent of their foreign investment (Keightley, 2013). By contrast, American multinationals reported earning just 14 percent of their profits in major U.S. trading partners with higher taxes-Australia, Canada, the UK, Germany, and Mexico-which accounted for 40 percent of their foreign workforce and 34 percent of their foreign investment. ${ }^{59}$

But the trick fact is that most of the profits booked offshore or disguised offshore profits are not the genuine profits generated offshore. Such huge profits are actually housed in U.S. banks or invested in American assets, but registered in the name of foreign subsidiaries. A Senate investigation of 27 large multinationals with substantial amounts of cash supposedly "trapped" offshore found that nearly half $(46 \%)$ of the funds that the surveyed corporations identified as offshore and for which U.S. taxes had been deferred, were actually in the U.S. at U.S. financial institutions by the end of financial year $2010^{60}$ (Linebaugh, 2013). For example, $93 \%$ of the money Microsoft booked offshore was invested in US assets. ${ }^{61}$

Aa general rule, the MNEs are barred from investing directly in their U.S. operations, paying dividends to shareholders or repurchasing stock with money they declare to be "permanently invested offshore". However, U.S. tax law contains an explicit series of exceptional rules which allow U.S. corporations to invest their foreign income in certain specified U.S. assets without characterizing that income as having been repatriated and without triggering the tax that would otherwise be associated with the return of those funds to the United States. ${ }^{62}$ Keeping the loopholes in the mind, the MNEs can easily evade the restrictive rules with aggressive schemes, such as borrowing at negligible rates using their offshore holdings as collateral. In such evasive cases, the MNEs do not need to pay taxes on the disguised "offshore profits" for tax purposes.

The U.S. has been continually frustrated and angered by the phenomenon of BEPS for more than five decades. On February, 2015, President Barack Obama has no choice but to propose a one-time "transition tax" on the offshore profits of all U.S.-based multinational corporations. His plan would tax these profits at a

\footnotetext{
${ }^{58}$ See Richard Phillips (2014), Steve Wamhoff, and Dan Smith, Offshore shell games 2014: The use of offshore tax heavens by fortune 500 companies, by Citizens for Tax Justice (CTJ), p. 12.

${ }^{59}$ See Mark P. Keightley (2013), An Analysis of Where American Companies Report Profits: Indications of Profits shifting, January 18, 2013.

${ }^{60}$ See Senate Permanent Subcommittee on Investigations, Dec. 14 2011. Offshore Funds Located On Shore, Majority Staff Report Addendum.

${ }^{61}$ See Kate Linebaugh, “Firms Keep Stockpiles of 'Foreign' Cash in US” Wall Street Journal, 22 January 2013.

${ }^{62}$ See (defining exceptions to "United States property").
} 
$14 \%$ rate immediately, rather than at the $35 \%$ rate that should apply absent the "deferral" loophole. This proposal would provide huge tax cuts to many corporations currently holding profits, often actually earned in the U.S., in low-rate foreign tax havens. According to his estimate, the U.S.-based companies have \$2 trillion profits overseas. ${ }^{63}$

Table 1 prepared by CTJ shows the detailed offshore profits and the tax breaks enjoyed by ten U.S.-based MNEs.

It is true that ten of the biggest offshore tax dodgers, including Apple, Microsoft and Citigroup would receive a collective tax break of $\$ 82.4$ billion for their 448.18 billion offshore profits. ${ }^{64}$ But, a bird in the hand is worth two in the bush. In my understanding, President Obama has no choice but to offer tax breaks to attract the offshore profits back to home, and therefore alleviate the magnitude of the BEPS schemes. Therefore, his politician compromise to the U.S.-based MNEs on the BEPS issue offers another strong evidence of the seriousness of BEPS schemes committed by the U.S.-based MNEs.

\subsection{The Magnitude of BEPS Schemes of Non-U.S.-Based MNEs}

Aggressive BEPS schemes are committed not only by the U.S.-based MNEs, but also by the MNEs based in other jurisdictions. Although there is no consensus on the exact magnitude of BEPS behaviors, the existence of aggressive BEPS scheme is a well-known fact. That is why OECD and G20 countries have called for international efforts to address the BEPS issue. For instance, G20 Leaders identified the need to address BEPS as a priority in their tax agenda at the Los Cabos Summit in June 2012. Since then, the G 20 countries have moved forward in fighting BEPS practices so that they ensure a fair contribution of all productive sectors to the financing of public spending in our countries. For the detailed data of the revenue loss in major jurisdictions arising from BEPS scheme, please see the discussion of the complicated disasters of BEPS schemes.

Furthermore, insufficient disclosure of exact magnitude and seriousness of BEPS behaviors, partly arises from insufficient disclosure and transparency on the side of the MNEs, partly arises from the lack of effective detection tools on the side of the governments. The lack of disclosure and transparency of BEPS does not imply the non-existence of BEPS behaviors. Quite contrary, it implies the necessity to update the current rules and standards to deal with the highly complicated and sophisticated BEPS behaviors. If the BEPS behaviors do not exist, the OECD and the government would have no need and pressure to launch a series of efforts to fight against BEPS behaviors.

\section{The Complicated Disasters of over Speculative BEPS Schemes}

As empirical evidence indicated, massive and various forms of BEPS have been adopted by the MNEs globally. However, most BEPS schemes are usually not

\footnotetext{
${ }^{63}$ The President's Budget for Fiscal Year 2016, http://www.whitehouse.gov/omb/budget.
}

${ }^{64}$ https://americansfortaxfairness.org/files/Corporate-Tax-Dodgers-Report-Final.pdf. 
Table 1. 10 Companies with biggest tax breaks from Obama's proposed 14\% transition $\operatorname{tax}$.

\begin{tabular}{ccccc}
\hline Company Name & $\begin{array}{c}\text { Unrepatriated } \\
\text { Income } \\
\$ \text { Millions }\end{array}$ & $\begin{array}{c}\text { Taxes Due on } \\
\text { Offshore } \\
\text { Profits }\end{array}$ & $\begin{array}{c}\text { Taxes Due } \\
\text { Under } \\
\text { Obama Plan }\end{array}$ & $\begin{array}{c}\text { Savings From } \\
\text { Obama Plan }\end{array}$ \\
\hline Apple & $\$ 137,100$ & $\$ 44,844$ & $\$ 17,938$ & $\$ 26,906$ \\
Microsoft & 92,900 & 29,600 & 11,840 & $\$ 17,760$ \\
Citigroup & 43,800 & 11,700 & 4,680 & 7020 \\
Oracle & 32,400 & 10,000 & 4,000 & 6000 \\
Amgen & 25,500 & 9100 & 3640 & 5460 \\
Qualcomm & 25,700 & 9100 & 3640 & 5460 \\
Eli Lilly & 23,740 & 8309 & 3324 & 4985 \\
J.P. Morgan Chase \& Co. & 28,500 & 6400 & 2560 & 3840 \\
Bbank of America Corp. & 17,000 & 4300 & 1720 & 2580 \\
Goldman Sachs Group & 22,540 & 4060 & 1624 & 2436 \\
Subtotal, 10 Companies & $\$ 449.180$ & $\$ 137,413$ & $\$ 54965$ & $\$ 82,448$ \\
\hline
\end{tabular}

considered as crimes or breaches of tax law. Many BEPS schemes are technically considered legal, lawful and even legitimate from the perspective of domestic tax law in many jurisdictions. Therefore, no jurisdiction seriously starts to ban and prosecuted the BEPS behaviors committed by the MNEs.

But, increasingly aggressive BEPS practices have caused a great number of undeniable, serious, lasting financial, cultural and emotional damages to the international community. The OECD Action Plan summarizes such harms at three levels of governments, individuals and businesses.$^{65}$ However, the OECD Action Plan has not exhausted all disasters of the BEPS behaviors may create. To achieve the consensus on taming and eradicate the unfair BEPS behaviors among the international community, it is necessary to analyze the BEPS harms in a detailed, comprehensive and concise way.

\subsection{The BEPS Schemes Have Seriously Eroded the Integrity of Tax Bases in Both Source and Residence Jurisdictions}

The MNEs, as super economic powers at world stage, are supposed to be the most significant taxpayers for the tax jurisdictions. However, they could easily employ the tax avoidance schemes and pay tax nowhere, thus harm both source countries and residence countries. This means, profitable multinationals firms have not paid the tax they are supposed to pay under the tax law. The over use of BEPS schemes have seriously eroded the tax bases in both source and residence jurisdictions, both developed countries and developing countries. BEPS schemes have caused substantial amount of tax revenue losses in many jurisdictions, and therefore threatened the tax sovereignty of all jurisdictions.

\footnotetext{
${ }^{65}$ Action Plan on Base Erosion and Profit Shifting $\odot$ OECD 2013, P. 8.
} 
US-based MNEs have been very experienced in eroding the tax base of the US, the residence jurisdiction. A study conducted by Greenlining Institute (2012) on the 30 top tech companies in the United States concludes that the ETR paid by these companies decreased from $23.6 \%$ in 2009 to $19.9 \%$ in 2010 and $16 \%$ in 2011. The study further notes that, at the end of 2009, United States companies had at least $\$ 1$ trillion of foreign retained earnings and considers this as a clear indication of profit shifting practices put in place by United States based MNEs. The amount is reported to be 1.7 trillion USD at the end of $2011 .^{66}$ In addition to the losses of the tax revenues, the sovereign states have to devote more extra financial and human resources to deter, detect and respond to the BEPS behaviors.

It is estimated that US-based MNEs are able to avoid an estimated $\$ 90$ billion in federal income taxes each year by booking profits to subsidiaries registered in tax havens (Phillips, et al., 2014). ${ }^{67}$ Over a four year period, Apple shifted $\$ 74$ billion in profits to an Irish entity that had no "tax residence" anywhere in the world, and thus owed minimal income taxes to any country. ${ }^{68}$ In 2013, Microsoft held $\$ 76.4$ billion offshore, and owed $\$ 24.4$ billion in U.S. tax. Google earned $\$ 6.2$ billion in UK in 2012 , but only pay $\$ 6$ million in corporate tax-a tax rate less than $0.3 \%$. Ironically, Amazon generated sales of more than $£ 3.3$ billion in the UK last year but paid no corporation tax on any of the profits. ${ }^{69}$

Furthermore, firms reporting fewer tax haven subsidiaries do not necessarily dodge fewer taxes offshore. According to the study of the Government Accountability Office in 2008, 83 of the top 100 publicly traded companies operated subsidiaries in offshore tax havens. Today, some companies report fewer subsidiaries in tax haven countries than they did in 2008. Meanwhile, some of the MNEs reported significant increases in how much cash they hold abroad, and pay such a low tax rate to foreign governments that it suggests the money is booked to tax havens.

There are two explanations for this phenomenon. First, MNEs are choosing not to disclose all of their subsidiaries, simply because the penalties for not disclosing subsidiaries imposed by SEC are relatively light, and MNEs are very nervous of the increased media attention on offshore tax dodging and/or IRS scrutiny. Second, MNEs are able to consolidate more income in fewer offshore subsidiaries, since single tax haven subsidiary is enough to dodge billions in taxes. For instance, Google reported operating 25 subsidiaries in tax havens in 2009, but since 2010 only discloses two, both in Ireland. During that period, it increased the amount of cash it had booked offshore from $\$ 7.7$ billion to $\$ 38.9$ billion. However, the 23 no-longer-disclosed tax haven subsidiaries were still oper${ }^{66}$ Addressing Base Erosion and Profit Shifting () OECD 2013, P. 62, 68.

${ }^{67}$ See Richard Phillips, Steve Wamhoff, and Dan Smith, Offshore shell games 2014: The use of offshore tax heavens by fortune 500 companies, by Citizens for Tax Justice (CTJ), p. 12.

${ }^{68}$ Crackdown on Apple in Ireland Opens Front on Tax Avoidance War

http://www.bloomberg.com/news/2014-09-30/crackdown-on-apple-in-ireland-opens-front-on-taxavoidance-war.htm.

${ }^{69} \mathrm{http}: / /$ www.bbc.com/news/business-20288077. 
ating as of 2012. Similarly, Microsoft reported operating 10 subsidiaries in tax havens, but only disclosed five in 2013, while its profits reported offshore was 12 times more (Phillips, et al., 2014). ${ }^{70}$

BEPS have also seriously eroded the tax base in Europe. In a recent Memo, the Commission quotes estimates of the scale of tax evasion. 1 It notes that shadow economy in the EU is estimated to amount to some $€ 2$ trillion, and that tax evasion is estimated to be around $€ 1$ trillion annually. It also notes that recent reports suggest that tens of billions of euros are held offshore, unreported and untaxed. $^{71}$

The developed countries are not the lonely victims. Developing countries' tax base has also been seriously eroded. Many developing countries welcome the MNEs to set up their subsidiaries, and hope the inbound foreign investment will help to expand the tax base in their territories. Expansion of the tax base is the core interest of the host countries. The tax revenue is very critical to foster the long term sustainable development of their national economies and public infrastructures. However, many developing countries are disappointed when they learn the fact that their tax base is eroded, instead of expanded by the MNEs, but their resources including natural resources, human capital and public services have been exploited by the MNEs.

According to a very cautious estimate of Global Financial Integrity, developing countries lose around $\$ 100$ billion a year due to the manipulation of transfer prices of enterprises. "They lose three times more money that they gain with development aid", wrote Melanie Ward form ActionAid in June 2013. ${ }^{72}$

Christian Aid's 2008 estimates more serious situation of base erosion in developing countries. It indicates that $\$ 160$ billion is lost annually to the developing world from tax evasion by multinationals and other businesses engaged in international trade seeking to minimize their tax liability has been questioned of late. $^{73}$

As World Bank and UNODC have the first class resources of research data, their research findings are more convincing. An estimate by the World Bank and UNODC suggests developing countries lose between $\$ 500$ - $\$ 800$ billion annually to illicit outflows' with tax evasion alone estimated to account for $40 \%$ of this. $^{74}$

Africa represents most typical developing countries in the world. According to

\footnotetext{
${ }^{70}$ Richard Phillips, Steve Wamhoff, and Dan Smith, Offshore shell games 2014: The use of offshore tax heavens by fortune 500 companies, by Citizens for Tax Justice (CTJ).

${ }^{71}$ European Commission Memo "Tackling tax fraud and evasion in the EU frequently asked questions", 27 June 2012.

http://europa.eu/rapid/pressReleasesAction.do?reference=MEMO/12/492\&format=HTML\&aged=0 \&language $=$ EN\&guiLanguage $=$ en $($ Accessed 17 August 2012).

${ }^{72} \mathrm{G} 20$ leaves developing world behind in tax evasion fight.

http://www.euractiv.com/development-policy/tax-evasion-g20-leaves-developin-news-530307.

${ }^{73} \mathrm{US} \$ 160 \mathrm{bn}$ the price of tax dodging in developing world,

${ }^{74}$ Estimating the extent to which tax evasion, avoidance and expenditures are undermining the 'Exit from Aid' in developing countries, http://r4d.dfid.gov.uk/Project/60670/.
} 
Kofi Annan, the former Secretary General of the UN, transfer mispricing costs Africa an average $\$ 38.4$ billion every year between 2008 and 2010, more than its inflows from either international aid or foreign direct investment. ${ }^{75} \$ 38.4$ billion every year mean a lot for the African children's right to food and education.

Although China is successful in attracting foreign investment and has become the world's largest destination for foreign direct investment, China is not successful in fighting against the aggressive BEPS schemes. The Income Tax Law on Enterprises with Foreign Investment and Foreign Enterprises of 1991 was not only silent on the BEPS schemes, but also offered most generous tax treatment to the MNEs, but unavailable to the domestic firms. Under Article 8 of this Law, any enterprise with foreign investment of a production nature scheduled to operate for a period of not less than 10 years shall, from the year in which it begins to make profits, be exempted from income tax in the first and second years and allowed a 50\% reduction in the third to fifth years. Although the five years of tax holidays were ended by the Law of Enterprise Income Tax of 2007, the general law governing both foreign firms and domestic firms, over aggressive BEPS practices have not attracted the attention of the legislature.

Although there is no precise empirical data on the exact scale of BEPS in China, the anti-avoidance efforts have made great progress. From the positive perspective, the anti-avoidance measures contributed 460 million RMB in 2005, and contribute 46.86 billion RMB in 2013 (Wu, 2014). ${ }^{76}$ For instance, China levied $\$ 140$ million in back taxes on Microsoft Corp. in November 2014, although Microsoft has denied that it practiced tax avoidance. From the negative perspective, some experts estimate that tax evasion and avoidance by foreign companies have resulted in an annual reduction of at least 30 billion yuan ( $\$ 4.9$ billion) in tax revenues. $^{77}$

Considering that the total internal revenue in China was 11.0479 trillion $\mathrm{RMB}$, among which, the corporate income tax was 2.2416 trillion $\mathrm{RMB},{ }^{78}$ the actual scale of the BEPS schemes might be greater than 76.86 billion RMB (\$12.81 billion). This means that BEPS scheme have seriously eroded the tax base in China. In response to the political consensus of the international community on fighting against BEPS, China will comprehensively monitor the profit levels of foreign companies to make sure there is no BEPS, and would coordinate with other countries to clamp down on BEPS plotting and cross-border tax avoidance.

It is time for the international community to work together to fight against the BEPS schemes, and to restore the integrity of tax bases.

\footnotetext{
${ }^{75}$ Kofi Annan, G20: how global tax reform could transform Africa's fortunes.

http://www.theguardian.com/commentisfree/2013/sep/05/g20-africa-global-tax-reform.

${ }^{76}$ See Qiuyu Wu, Fix the Loopholes of BEPS,

http://finance.people.com.cn/n/2014/1013/c1004-25818469.html.

${ }^{77}$ See Li Xiang, Foreign firms set for tougher tax scrutiny,

http://europe.chinadaily.com.cn/business/2014-12/03/content_19013775.htm.

${ }^{78}$ See Xinhua, China to prevent international firms from avoiding tax,

http://usa.chinadaily.com.cn/business/2014-12/02/content_19007409.htm
} 


\subsection{The BEPS Schemes Have Deteriorated the Quality of the Public Goods in All Relevant Jurisdictions}

Theoretically speaking, the tax is the price paid by the MNEs to survive and develop in the world. The tax is just like the bridge between the MNEs and the society, the bond that keep the MNEs and the society together. No firm is doing business in the vacuum. As the basic social and economic cells in the modern world, the MNEs need to grab various forms of nutritions for the outside world, including but not confined to education system, financial system, public infrastructure, national defense, judicial system, consumer market and social security systems. There is no free lunch in the world. The MNEs are supposed to pay the tax for accepting the above mentioned privileges and services.

However, the erosion of the tax base and the loss of the tax revenues could seriously weaken the governmental expenditure on the public infrastructures and services, and could deteriorate the public welfare of the jurisdictions substantially relevant to the MNEs. Failure to pay the tax by the use of BEPS has a series negative consequences.

First, the BEPS scheme hurt the education system and the future of the children in every nation. The sustainable MNEs heavily depends on the healthy labor market and education system including $\mathrm{K}+12$ mandatory education system, the college and graduate education system, and continuing education system to provide for the skilled labor force such as professionals, executives, engineers and administrative staffs. The government and the society have to finance the public education system especially the pre-college system with the contribution of all the taxpayers including the MNEs. When the MNEs abuse the BEPS opportunities, the quality of education system will be deteriorated due to lack of skilled faculty members and management. The bad quality of public education will hurt the whole life of the next generation. To keep the minimum academic standard of the education, the parents have to pay unreasonable extra tax or make more involuntary donations when the MNEs refuse to pay the fair payment of the tax.

As the government has to cut down the budget for the public elementary schools as BEPS scheme become crazy, education elites have no incentive to join the faculty. To support their family, some of the faculty members have to engage in a part time job irrelevant to their job in the school. This author personally knows a counsel in a pubic elementary school in Ann Arbor, Michigan, who is a part time real estate broker. His only purpose to make extra money to support the college education of his daughter.

Second, the BEPS scheme hurt the financial system. The sustainable development of the MNEs heavily depends on the dynamic financial market, including the banking system, capital market and sound regulatory system. The MNEs are the biggest beneficiary of the healthy financial system including stable currency and financing platforms. Regardless of the ownership of the financial institutions, either the private financial institution or the public financial institution, all the taxpayers have to finance the restructuring of the broken financial system. 
The secret and simple reason are that almost all the politicians and the public have to follow the absurd rule of "too big to fail". Actually, "too big to fail" has no legitimacy at all. Its true nature is to and kidnap and blackmail the public taxpayers by some giant financial institutions. Another disastrous consequence of "too big to fail" is "too big to bail". That is why the G20 decided to end "too-big-to-fail" in 2014: Reforms to enable governments and authorities to resolve financially distressed and systemically-important institutions in such a way as to avoid disruption to the financial system and without exposing the taxpayer to the risk of loss. ${ }^{79}$

In the Wall Street financial crisis, some American financial institutions bailed out by the government, ultimately by the taxpayers, are still greedy with the aggressive BEPS scheme. It is like a millionaire disguising as a homeless person, taking the money form the pocket of the poor people with the left hand, and hiding his money in a dark corner with his right hand. For instance, Bank of America, Citigroup, JP Morgan-Chase, AIG, Goldman Sachs, Wells Fargo and Morgan Stanley all large financial institutions that received taxpayer bailouts in 2008-disclose a combined 702 subsidiaries in tax havens ${ }^{80}$ (Phillips, et al., 2014).

It does not make any sense for the wrongdoer financial institutions to be rewarded for their wrongdoings by the public taxpayers. The BEPS schemes used by non-financial MNEs also hurt the financial system in the long run. No wonder why President Obama proudly declared in the State of Union 2015, "Today, we have new tools to stop taxpayer-funded bailouts, and a new consumer watchdog to protect us from predatory lending and abusive credit card practices". ${ }^{81}$ But American taxpayers have paid expensive price for the change of policy.

Third, the BEPS scheme hurt the public infrastructure. The MNEs need to utilize the road to transport the raw materials and to deliver the goods. The MNEs need the police service provided by the government and the judicial service provided by the courts. The MNEs also need the defense service of the government in order to enjoy a peaceful environment for doing business. When the BEPS schemes are aggressively used, all the public infrastructure and public service will be worse off. For instance, the government with modest revenue is usually unable to build the high-speed rail network and rebuild the too free road of extended active duty. The low rank of public infrastructure and public service not only injure the ordinary citizens, but also injure the MNEs themselves. Although in case of governmental failure, the private market could step in to offer the public goods or services, such commercial goods or services are not inclusive and not free for ordinary citizens as the public goods or services offered by the government.

When he mentioned the investment on the infrastructure and basic research ${ }^{79}$ https://g20.org/wp-content/uploads/2014/12/FAQs-g20-agenda.pdf

${ }^{80}$ See Richard Phillips, Steve Wamhoff, and Dan Smith, Offshore shell games 2014: The use of offshore tax heavens by fortune 500 companies, by Citizens for Tax Justice (CTJ), p. 7.

${ }^{81}$ http://www.cnn.com/2015/01/20/politics/state-of-the-union-2015-transcript-full-text/. 
in the State of Union 2015, President Obama said, "Where we too often run onto the rocks is how to pay for these investments. As Americans, we don't mind paying our fair share of taxes, as long as everybody else does, too. But for far too long, lobbyists have rigged the tax code with loopholes that let some corporations pay nothing while others pay full freight. They've riddled it with giveaways the superrich don't need, denying a break to middle class families who do". ${ }^{82}$

Considering the serious impacts on the quality of life of ordinary citizens caused by the BEPS schemes, G20 leaders are committed to ensure countries receive the taxes they are due; revenue which can then be used to provide infrastructure and services to benefit their citizens. ${ }^{83}$

\subsection{The BEPS Schemes Have Fundamentally Undermined the Tax Justice, and Unreasonably Imposed Unfair Burden on Domestic Taxpayers Especially the Individuals and Small Businesses}

Tax justice is the core value of modern tax law. Tax justice is not only applicable to the institutional arrangement of tax law, but also applicable to the legal enforcement of tax law. It is important for the tax justice existing in the tax law in the book. It is important for the tax justice to be rooted in the practice. There are two requirements of tax justice: fairness and effectiveness.

Fairness is the fundamental characteristic of the tax justice. First, fairness means that every taxpayer pays the tax in return for the public service. No payment of the tax, no access to the public service. Second, fairness demands the equal treatment or national treatment of the multinational taxpayers and domestic taxpayers. Each and every tax payer is supposed to pay the due tax imposed by the tax law, regardless of the citizenship or ownership of the taxpayers. Both MNEs and domestic corporations should equally demonstrate the tax integrity. Third, fairness demands the tax burden commensurate with the wealth. The rich tax payers with more economic powers should pay more tax as than the poor tax payers. The MNEs grab tremendous resources from the society and generate huge benefits from the resources they control. They are supposed to pay more tax, at least no less than the tax paid by domestic taxpayers, including the individual and corporate taxpayers.

According to the requirements of tax fairness, international tax rules are designed to expect that MNEs will pay tax somewhere on their global profits, either in source countries, or in residence countries. However, such expectation is fundamentally frustrated by the over aggressive BEPS practices. As a result, the MNEs pay no or unreasonably low tax, which seriously destroys the fairness of the tax law.

A recent OECD study has concluded that "some multinationals use strategies that allow them to pay as little as $5 \%$ in corporate taxes when smaller businesses are paying up to $30 \%$ ", with "some small jurisdictions act as conduits, receiving ${ }^{8}$ http://www.cnn.com/2015/01/20/politics/state-of-the-union-2015-transcript-full-text/.

${ }^{83}$ http://www.pm.gov.au/media/2014-11-16/g20-helps-restore-fairness-global-tax-system. 
disproportionately large amounts of foreign direct investment compared to large industrialized countries and investing disproportionately large amounts in major developed and emerging economies" ${ }^{84}$ (OECD, 2013).

Although the tax burden is supposed to be shared by all taxpayers, the BEPS schemes crucially shift the tax burden of MNEs to other honest taxpayers, and unreasonably increase the tax burden of domestic taxpayers. The wealthy, profitable multinational taxpayers pay no or unreasonably low tax, while the less wealthy but more honest domestic individual and corporate taxpayers pay more tax. The biggest beneficiary of the resources and public service pays less tax than other smaller beneficiary of the social resources and public services. Such abnormal phenomenon is totally against the core value of the tax justice.

The traditional governmental reactions to the BEPS usually create new unfairness to the innocent domestic taxpayers, especially the individuals and small businesses. According to the U.S. Congressional Research Service, the share of corporate income taxes in the United States has fallen from a high of $32 \%$ of federal tax revenue in 1952, to less than $10 \%$ in 2012. Meanwhile, payroll taxes-which almost every working American must pay-have increased from 10\% of federal revenue to $35 \% .{ }^{85}$

As the sovereign states are unable to collect sufficient revenues from the BEPS MNEs, they have to either impose new taxes to the honest firms especially domestic companies, or strengthen the tax administration of the domestic companies. On either of the circumstances, the source jurisdictions will punish the innocent domestic corporations, and tolerate or even reward the dishonest MNEs. It is natural that the innocent domestic corporations will hate the unfairness of new tax responses, when they are required to pay the bill for the MNEs' BEPS behaviors. In other words, the real patient has not been hospitalized, while other healthy people are forced take the pills for the decease suffered by the real patient.

The BEPS behaviors have not only fundamentally undermined the fairness of tax justice, but also destroyed the effectiveness of the tax justice. The effectiveness of the tax justice refers to the competence or capacity to cary the value of fairness into the reality. The tax justice should not only be expressed in the black letter in the book, but also be translated into the practice, and deeply rooted in the heart of the taxpayer. The evil always lies in the details. BEPS also lies in the details, not in the general rules of tax law. Although there are huge amount of tax law rules and tax treaties to express the value of the tax justice and fairness, BEPS schemes still exist there. This means that the BEPS schemes always beat the effectiveness of tinstrumentice.

Of course, the success of the BEPS schemes imposes a pressure on the global ${ }^{84}$ See OECD, 2013, OECD urges stronger international co-operation on corporate tax [online], http://www.oecd.org//newsroom/oecd-urgesstronger-international-co-operation-on-corporate-tax. htm (Accessed 14 February 2013)

${ }^{85}$ United States Senate Permanent Subcommittee on Investigations, ACTIVITIES REPORT, 113 ${ }^{\text {th }}$ Congress (2013-14), December 19, 2014. 
legislatures, the policy makers and the tax authorities to improve the legal rules and the mechanism for enforcing the tax law. Because, it is stupid to hold the cat with the cattle pen.

\subsection{The BEPS Schemes Have Distorted the Free and Fair Mechanism of Market Competition}

Free and fair competition is the driving force of the modern market economy. Competition encourages the technology innovation, expands the range of choices for the consumers, creates jobs and revenues, facilitate the growth of giant firms, and protect the booming business of small and micro firms. Competition law could be considered as the "constitutional law" in the modern age.

The competitiveness of the firms not only depend on the quality and price of the products or services, but also depend on the fair tax treatment and burden. Therefore, competition law is not the only legal instrument for restoring the dynamics of the market competition. Tax law especially international tax law also has significant role to play to safeguard the competition system by controlling the BEPS scheme.

"Bad money drives out good". The MNEs, by abusing the aggressive tax planning strategies worldwide, could gain huge unfair comparative competitive advantages, against local competitors, especially small businesses operating at the domestic level. However, honest firms especially the domestic corporations are unable to acquire such comparative competitiveness. By engaging in speculative and excessive BEPS schemes, dishonest MNEs become stronger and stronger, while honest domestic firms especially micro-small firms will get weaker and weaker.

Therefore, in addition to substantially decreasing the government revenue, BEPS schemes have eroded the effectiveness of fair competition, violated competitor's right to seriously development, distorted the fair competition mechanism, and put honest competitors at comparable competitive disadvantages. To create a level playing field, it is necessary and urgent to fight against the opportunistic BEPS schemes.

\subsection{The BEPS Schemes Have Seriously Undermined the Efficiency of Rational Market in Optimal Allocation of the Resources and Created a Booming Intermediary Industry Assisting BEPS}

The market economy has been considered more efficient than the planned economy in the world including China and many other countries with the history of decades of planned economy. The difference between the market economy and the market economy is which is the primary decision make in organizing the production and distribution of the products or services. In planned economy, the government is considered as the smart planner of all micro economic activities and the authority of the allocation of the resources. In market economies, the market plays the decisive role in the free movement and optimal allocation of resources. The efficient market should be capable of allocat- 
ing the capital, labor and other resources on a rationale basis, and optimizing the overall welfare of the society as a whole.

The MNEs are the children of the market economy. As the active market participants, the MNEs contribute to the growth of the market economy. However, once the dignity of the tax justice is humiliated, the tax effectiveness will also disappear. Over aggressive BEPS schemes have seriously undermined the efficiency of rational market in optimal allocation of resources. The BEPS strategies may distort investment decisions towards activities that have lower pre-tax rates of return, but higher after-tax rates of return. ${ }^{86}$ Under the influence of BEPS behaviors, abundant resources have been artificially shifted to the MNEs in an unreasonable way, with other market participants and stakeholders in the source jurisdiction left behind.

Ironically, great demand for BEPS has created a booming intermediary industry engaging in assisting BEPS schemes. Consequently, the aggressive BEPS schemes have made it very difficult, if not impossible, for the resources to flow into the hand of the firms, which are able to advance the maximum welfare of the society.

\subsection{BEPS Schemes Have Seriously Undermined the Reasonable Trust of Global Taxpayers in the Fairness and Integrity of the Tax law, and Hindered the Voluntary Compliance by the Public Taxpayers}

The rule of law is the best form of public governance. In my opinion, there are four pillars of the rule of law: transparent and democratic legislation system, uniform and effective regulatory system, fair and efficient judiciary system, and the voluntary compliance system. The good law is not the whole story. The good law must be enforced and complied by all the citizens including corporate citizens.

As far as the tax law is concerned, the tax law deserves to be respected, worshiped, believed, trusted and protected by all tax payers. Without the firm belief on the rule of tax law, there would be no tax justice. The power, authority and strength of tax law totally depend on the belief and trust on the tax law from the heart of every taxpayer, either resident or non-resident. Ideally, voluntary compliance with the tax law should be a customary and unconsciously way of life for the taxpayers. Taxpayers have good reason to believe that other taxpayers will also comply with the governing tax law. If every taxpayer think in this way, the society will have a strong and sustainable belief on the authority of tax law.

In 1982, Social scientists James Q. Wilson and George L. Kelling introduced the broken windows theory, which is a criminological theory of the norm-setting and signaling effect of urban disorder and vandalism on additional crime and anti-social behavior. ${ }^{87}$ This theory is also valid as to the circumstance of BEPS schemes. The negative signaling effect of the BEPS schemes is even more dis-

${ }^{86}$ Addressing Base Erosion And Profit Shifting (C) OECD 2013, P. 8.

${ }^{87}$ https://en.wikipedia.org/wiki/Broken_windows theory. 
astrous than the billions of dollars of dodged revenues.

The increased attention and the inherent challenge of dealing comprehensively with such a complex subject has encouraged a perception that the domestic and international rules on the taxation of cross-border profits are now broken and that taxes are only paid by the naive. ${ }^{88}$ Once learning the fact of the BEPS schemes committed by the MNEs, the public taxpayers will be disappointed and desperate about the rule of law. Disappointed taxpayers will turn to follow the model of the BEPS schemes, and develop similar aggressive tax planning strategies or simply refuse to pay the tax. This is the race to the bottom of the broken windows. It is extremely difficult to restore the confidence of the public taxpayers on the integrity of the tax law.

Although the best strategy to deal fix the broken window is zero tolerance of the BEPS schemes, it is impossible for any single jurisdiction to fix the first broken window. It is urgent to innovate and reform the traditional tax law rules worldwide, so as to restore the public confidence and trust in the fairness and integrity of the tax system, and to encourage the taxpayers to voluntarily comply with the tax law. Of course, it will take time to fix all the broken windows in the international tax law.

\subsection{The BEPS Schemes Have Seriously Injured the Reputation of the Community of MNEs and Worsened off the Global Business Ecology}

The available data indicates many MNEs get involved into the scandals of too aggressive BEPS schemes. However, there is no convincing evidence to support that all the MNEs have practiced aggressive BEPS schemes. As the disclosure of the BEPS schemes is still insufficient, the public is unable to identify the honest MNEs from the international business community. Therefore, the public has good reason to presume that each and every MNE has committed BEPS scheme. Theoretically speaking, honest MNEs still have the opportunities to produce sound evidence to prove their innocence. However, the credibility of such evidence is still doubtful, as many MNEs especially corporations not listed at stock exchanges, have not disclosed all the information about their active BEPS schemes, especially the full amount and actual functions of their subsidiaries in the tax haven jurisdictions.

Honest MNEs would refrain themselves from engaging the speculative BEPS schemes, although the existing opportunities created by the loopholes, frictions or gaps of international tax regulation mean a big deal of profits. Reasonable MNEs usually pay attention to the speculative BEPS schemes used by their counterparts. They could also carefully and seriously evaluate their repetitional risk brought by other greedy and dishonest MNEs. Although the honest MNEs try to be insulated from the opportunistic MNEs, they still find them suffering competitive disadvantage, if the public and international community is unable to differentiate the honest MNEs from the opportunistic MNEs.

${ }^{88}$ Addressing Base Erosion and Profit Shifting (c) OECD 2013, P. 13. 
As it is difficult or even impossible to differentiate the honest MNEs from the over speculative MNEs, the public and sovereign states have solid ground to consider all the MNEs including the honest MNEs as the aggressive, speculative MNEs for the purpose of BEPS. Such a widespread perception could seriously damage the reputation of all the MNEs and worsened off the global business ecology. It is unfair for the innocent MNEs. But it is the fact. The tricky reason is that all the MNEs are rowing the same boat before all the BEPS information is made transparent to the public.

Glory and pride, based on the responsibility and integrity, are the best assets of the MNEs. There are pros and cons about the MNEs including the MNEs with the BEPS record. Even the MNEs with the BEPS record play positive social roles in some respects. To be honest and objective, the MNEs have contributed a lot in advancing the innovation, developing the economy and improving the people's life. Almost every person's life has been greatly changed by the new technologies, new products and new services brought by the MNEs. Information and communication technology is just one of the innumerable great modern innovations. However, once the MNEs' reputations are negative at least for the purpose of BEPS, the positive contributions will be ignored by the public. Even if these performances are recognized, the public still has the right to consider the performances as the selfish, utilitarian instruments or shows, not the core value of social responsibility, for maximizing the profits of MNEs.

As the public opinion is full of angry about the speculative opportunism of MNEs for the highly complicated BEPS schemes, all the MNEs will be distrusted, hated, reprimanded and condemned. Of course, the MNEs still have opportunities to repair their reputation and regain their credibility by merely behaving themselves, abolishing the over excessive BEPS schemes worth of trillion dollars. The danger is, if the MNEs refuse or fail to make a fresh start, the global business ecology has no choice but to be deteriorated further. To make the justice done, the sovereign states and the international community have to take tough position to regulate the MNEs, which could have negative impacts on the sustainable development. The best interest especially the long term interest of the MNEs will be reoriented and interpreted to some extent.

\section{Conclusion}

The MNEs are just like the jelly fish. They are nowhere, but everywhere. BEPS schemes abused by the MNEs have caused serious, lasting and irreparable harms to all the stakeholders of the international community, from developed countries to developing countries, from the source countries to the residence countries. The over speculative BEPS schemes are not only hurting the others, but also hurting the MNEs themselves. Hence, the over speculative BEPS scheme is not smart win-win game, but stupid lose-lose game. It is not the virtue of the global market economy. It is the tumor in the beautiful body of the global economy. That is why this author conducts the research on the regulation of the BEPS schemes. 
From 2013 to 2015, the OECD developed a series of actions designed to address BEPS activities by multinational enterprises, culminating in a final report of 15 action steps. On November 24, 2016, the OECD published the text and commentary for a new multilateral tax instrument (MLI). The MLI will implement minimum standards to counter treaty abuse and to improve dispute resolution mechanisms while providing flexibility to accommodate specific tax treaty policies. It will also allow governments to strengthen their tax treaties with other tax treaty measures developed in the OECD/G20 BEPS Project. On 7 June 2017, Ministers and other high-level representatives of over 70 jurisdictions participated in the signing ceremony of the MLI in Paris.

Although the endorsement of MLI is a critical turning point for the global community to fight against BEPS schemes, the efficiency of the OECD/G20 BEPS package depends on the meaningful reactions from both the national governments and the multinational corporations. As countries are competing for the international capital and nationalism and unilateralism prevail in some countries, the race to the bottom might happen. That means the ambitious international efforts against BEPS schemes might be compromised in the practice. To remind the countries and multinationals to be aware of the serious disasters of BEPS scheme, this author hopes the politicians and business leaders to read this paper so as to move forward to implement the BEPS project in a more consistent, coordinated and coherent way.

\section{Conflicts of Interest}

The author declares no conflicts of interest regarding the publication of this paper.

\section{References}

Audit Analytics (2014). Overseas Earnings of Russell 1000 Tops \$2 Trillion in 2013. https://blog.auditanalytics.com/overseas-earnings-of-russell-1000-tops-2-trillion-in-20 $\underline{13 /}$

Avi-Yonah, R. S., \& Xu, H. (2016). Evaluating BEPS: A Reconsideration of the Benefits Principle and Proposal for UN Oversight. Harvard Business Law Review, 6, 185-238.

Avi-Yonah, R. S., Sartori, N., \& Marian, O. (2011). Global Perspectives on Income Taxation Law (pp. 101-102). Oxford: Oxford University Press.

https://doi.org/10.1093/acprof:oso/9780195321357.003.0007

Avi-Yonah, R., \& Lahav, Y. (2011). The Effective Tax Rate of the Largest US and EU Multinationals. Ann Arbor, MI: University of Michigan Law School, Program in Law \& Economics, Working Paper No. 41. https://doi.org/10.2139/ssrn.1949226

https://repository.law.umich.edu/cgi/viewcontent.cgi?referer=https://cn.bing.com/\&htt psredir $=1 \&$ article $=1150 \&$ context=law econ current

Bartlett, B. (2013). Effective Corporate Tax Rates. New York Times, November 26.

CTJ Staff (2013). Price Water House Coopers Report Quietly Confirms Low Effective Tax Rates for Corporations, But Directs Attention to Irrelevant Figures.

Keightley, M. P. (2013). An Analysis of Where American Companies Report Profits: Indications of Profits Shifting. 
Linebaugh, K. (2013). Firms Keep Stockpiles of "Foreign" Cash in US. Wall Street Journal, 22 January.

http://online.wsj.com/article/SB10001424127887323284104578255663224471212.html

Lyon, A. B. (2010). Another Look at Corporate Effective Tax Rates, 2004-2010.

http://www.brt.org/sites/default/files/legacy/uploads/general/Lyon-Effective $\% 20 \mathrm{Tax} \% 2$ 0Rates-Tax\%20Notes\%20Oct\%2021\%202013.pdf

Markle, K. S., \& Hackelford, D. A. (2011). Cross-Country Comparisons of Corporate Income Taxes. Cambridge, MA: National Bureau of Economic Research Working Paper No. 16839. https://doi.org/10.3386/w16839

McIntyre, R. S., Gardner, M., \& Phillips, R. (2014). The Sorry State of Corporate Taxes: What Fortune 500 Firms Pay (or Don't Pay) in the USA and What they Pay Abroad-2008 to 2012.

https://www.ctj.org/wp-content/uploads/2017/11/sorrystateofcorptaxes.pdf

Miller, M. M. (2013). Analysis Shows GAO Got It Wrong on the Corporate Effective Tax Rate.

http://businessroundtable.org/media/blog/analysis-shows-the-gao-got-it-wrong-on-the -corporate-effective-tax-rat

OECD (2013). OECD Urges Stronger International Co-Operation on Corporate Tax. http://www.oecd.org/tax/oecd-urges-stronger-international-co-operation-on-corporate -tax.htm

Phillips, R., Wamhoff, S., \& Smith, D. (2014). Offshore Shell Games 2014: The Use of Offshore Tax Heavens by Fortune 500 Companies, by Citizens for Tax Justice (CTJ).

PwC (2011). Global Effective Tax Rates, April, 2011. http://businessroundtable.org/sites/default/files/Effective Tax Rate Study.pdf

PwC US Issues (2014). Tax Rate Benchmarking Study for Industrial Products and Automotive Sectors.

https://www.prnewswire.com/news-releases/pwc-us-issues-2014-tax-rate-benchmarkin g-study-for-industrial-products-and-automotive-sectors-261966241.html

Sullivan, M. A. (2013). Behind the GAO’s 12.6 Percent Effective Corporate Rate. http://taxprof.typepad.com/files/140tn0197.pdf

Wells, B., \& Lowell, C. (2014). Tax Base Erosion: Reformation of Section 482's Arm's Length Standard. Florida Tax Review, 15, 737-797. https://doi.org/10.2139/ssrn.2310882

Weyzig, F. (2013). International Finance and Tax Avoidance via Dutch Special Purpose Entities. Paper for Presentation at Research Seminar, Radboud University Nijmegen, 21 October.

Wu, Q. (2014). Fix the Loopholes of BEPS.

http://finance.people.com.cn/n/2014/1013/c1004-25818469.html

Yorgason, D. R. (2009). Collection of Data on Income and Other Taxes in Surveys of U.S. Multinational Enterprises. In 4th Joint Session of the Working Group on International Investment Statistics.

http://www.bea.gov/papers/pdf/Yorgason multinational taxes.pdf 